Mariana Ferreira Cardoso da Silva

VinCUlaÇÃo de DeCisões do STF: ASPECTOS

Normativos, INSTITUCIONAIS E CULTURAIS

Orientador: Professor Marcos Paulo

Veríssimo.

São Paulo

2014 
MARIANA FERREIRA CARDOSO DA SILVA

\title{
A Vinculação de Decisões do STF: Aspectos Normativos, InSTITUCIONAIS E CULTURAIS
}

\begin{abstract}
Dissertação apresentada como requisito parcial para obtenção do título de Mestre em Direito pelo Programa de Pósgraduação da Faculdade de Direito da Universidade de São Paulo.

Área de concentração: Direito do Estado Orientador: Professor Marcos Paulo Veríssimo.
\end{abstract}

Faculdade de Direito da Universidade de São Paulo São Paulo, 2014. 
Silva, Mariana Ferreira Cardoso da.

Vinculação de decisões do STF: Aspectos normativos, institucionais e culturais / Mariana Ferreira Cardoso da Silva - 2013. 99 f.

Orientador: Marcos Paulo Veríssimo.

Dissertação (mestrado) - Universidade de São Paulo. 


\section{VinCUlAÇÃo de DeCisões do STF: AsPeCTOS NoRMATIVOS, InSTITUCIONAIS E CULTURAIS}

Dissertação apresentada como requisito parcial para obtenção do título de Mestre em Direito pelo Programa de Pósgraduação da Faculdade de Direito da Universidade de São Paulo.

Data de Aprovação

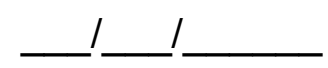

Banca Examinadora:

Professor Marcos Paulo Veríssimo.

São Paulo, 2014. 


\section{Agradecimentos}

Agradeço ao meu orientador, Marcos Paulo Veríssimo, pela confiança no meu trabalho e pelas valiosas contribuições à presente pesquisa.

A Diogo Coutinho e Virgílio Afonso da Silva pelas críticas construtivas feitas durante a banca de qualificação. Ao primeiro, especialmente, pela estímulo inicial à pesquisa e o incentivo à realização de um mestrado. Ao segundo, por proporcionar espaço para o debate acadêmico de alto nível de Direito Constitucional.

Aos queridos amigos, Rafael Belém de Lima, pelas conversas intermináveis sobre as ideias desta pesquisa, e a Paula de Figueiredo Silva e a Leonardo Rocha Bento, pela revisão e críticas à presente dissertação.

À toda a minha família e, em especial, aos meus pais, Mário Roberto e Dyleine, pelo amor e pelo apoio incondicional a todos os meus projetos pessoais e profissionais.

Agradeço, por fim, a Eduardo Balestrero Thiele, companheiro de todas as horas, pelo carinho e pela compreensão irreparável nas longas horas dedicadas a este trabalho. 


\section{Resumo}

Desde a promulgação da Constituição de 1988, mecanismos de vinculação de decisões foram introduzidos no sistema jurídico brasileiro, com vistas, principalmente, à redução da sobrecarga de trabalho do Judiciário. A autora argumenta que peculiaridades institucionais e culturais brasileiras, como os procedimentos de deliberação e tomada de decisão no STF e as formas de estruturação e justificação das decisões, seriam fatores obstativos à operacionalização de práticas decisórias pautadas na aplicação de precedentes. Ademais, ao endereçar tão somente o plano normativo, as reformas em curso chancelariam o modelo deliberativo e decisório do tribunal, revelando uma maior preocupação com a vinculação dos juízos inferiores do que uma valorização dos precedentes da corte. Não obstante os fatores refratários às mudanças em curso, a autora argumenta que é possível que a introdução progressiva de mecanismos de vinculação de instâncias inferiores possa implicar mudanças mais profundas na praticas deliberativas da corte e na condução discursiva de seus julgados. A exposição é segmentada em cinco partes. A autora, inicialmente, trata dos pressupostos teóricos que sustentam a hipótese de trabalho; expõe, em seguida, as modificações normativas que instituíram formas de vinculação judicial a precedentes; aborda então os fatores institucionais problemáticos a operação de retomada e replicação de precedentes; e, finalmente, discute como a ausência de uma cultura de precedentes no Brasil interfere na efetividade das reformas em curso.

Palavras chave: Precedentes; Vinculação; Desenho institucional; Deliberação; Supremo Tribunal Federal (STF); 


\begin{abstract}
Since the promulgation of the Constitutional Charter of 1988, there were reforms in the Brazilian legal system aimed at introducing adherence to precedents. The author argues that institucional and cultural peculiarities, such as deliberation procedures, the decision-making process and the practices of structuring and justification in the judicial decision writing were hindrances to the implementation of those reforms. Besides, changes were restrained to the normative level, therefore, leaving untouched the deliberative model of the tribunal. They revealed a strong concern with the submission of lower courts, rather than recognition of the importance of precedents by itself. Nevertheless, the author argues that, in the long term, the imposition of adherence to precedents may entail changes in the decision-making process and in the deliberative practices of the tribunal. The paper is divided into five parts. Initially, the author discusses the theoretical assumptions which underpin her hypothesis. The second part explains normative aspects of the ongoing reforms. The third and fourth sections deals with institutional and cultural factors related to judicial decision-making and adherence to precedents.
\end{abstract}

Keywords: Precedents; Brazilian Supreme Court (Supremo Tribunal Federal); Stare decisis and civil law; Institutional choice; Judicial deliberation; 


\section{ÍNDICE}

I. Introdução ..................................................................................................................9

II - Proposição do problema e plano de pesquisa ............................................12

III - Duas formas distintas de pensar o direito .................................................19

IV. Positivação de mecanismos de vinculação judicial em sistema civil law

IV. 1. Vinculação de decisões em sede de controle abstrato de constitucionalidade .............................................................................................3

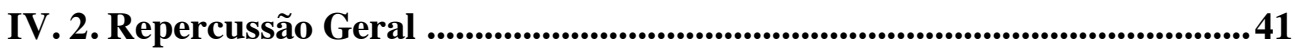

IV.3. Súmula Vinculante ...........................................................................................45

IV. 5. Resultados quantitativos observados em relação à introdução das mudanças normativas..........................................................................................55

V. Fatores institucionais relacionados à vinculação a precedentes. ............61

V. 1. O desenho institucional do STF e sua multiplicidade de funções .............62

V. 2. Procedimentos decisórios no Supremo Tribunal Federal ............................66

V. 3. A vinculação em controle difuso: a tese da mutação constitucional..........73

V. 4. A interação externa: a publicidade das sessões de julgamento do STF ..75

VI. Cultura de precedentes e vinculação.........................................................79

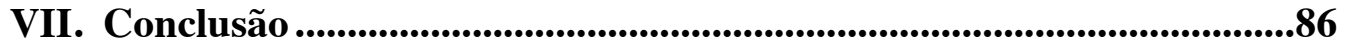

VIII. Bibliografia ..................................................................................................99 


\section{Introdução}

Em termos gerais, a presente pesquisa pretende tratar das recentes transformações promovidas, de um lado, por mudanças normativas e institucionais voltadas à vinculação de decisões e, de outro, por uma resistência institucional e cultural, a neutralizar, em parte, a efetividade dessas reformas. A motivação central para a realização deste trabalho foi tentar compreender como operam, na prática, essas tendências contrárias, desencadeadas por reformas procedimentais e matizadas pela tradição jurídica na qual se inserem.

O pano fundo desse debate é o fenômeno da judicialização, entendida como o fortalecimento do papel do Judiciário como instituição e da jurisprudência como uma fonte do direito em países de civil law, que, portanto, não estavam habituados a essa precedência do Judiciário. Entendida como incremento do papel do judiciário na criação e desenvolvimento do direito, a judicialização tem propiciado significativo aumento no poder atribuído aos juízes e tribunais ${ }^{1}$.

\footnotetext{
${ }^{1}$ Tate e Vallinder explicam que o fenômeno da judicialização desdobrar-se-ia em tendências relacionadas à atuação do próprio judiciário, bem como dos demais atores sociais e políticos, dentre as quais ressaltam: (i) maior presença de decisões judiciais como forma de solução de problemas políticos, econômicos e sociais; (ii) maior presença de cortes e processos judiciais na vida política e social; (iii) e, em contrapartida, maior utilização de estratégias legais e judiciais por atores sociais, porquanto necessários menores esforços de organização políticosocial. Neal Tate, Torbjörn Vallinder. The Global Expansion of Judicial Power. Nova York: New York University Press, 1995.
} 
A maior presença de decisões judiciais como forma de solução de problemas políticos, econômicos e sociais e a maior utilização de estratégias legais e judiciais por atores sociais tornaram o Judiciário uma verdadeira arena de exposição e resolução de conflitos os mais variados. A impossibilidade de ser dada vazão às crescentes demandas de juridificação acarretou a necessidade de métodos de racionalização do trabalho e uniformização da jurisprudência.

Ainda que já latentes em um momento anterior, mudanças de direito positivo tendem a escancarar problemáticas de dinâmica institucional e legitimidade democrática, fomentando a reflexão e o debate. A possibilidade de vinculação de decisões, com vistas a promover a racionalização da atividade judicial, acaba por resultar em aumento exponencial do poder arrogado ao Judiciário, evidenciando a perda do - outrora talvez compreendido como exclusivo - controle de introdução de novas regras jurídicas no ordenamento por parte do Poder Legislativo. A maior deferência à jurisprudência na resolução de conflitos define, assim, uma verdadeira metamorfose da dinâmica de separação de poderes.

A atribuição de caráter vinculante às decisões judiciais, são acompanhadas, muitas vezes, de rearranjos institucionais, voltados à redução da sobrecarga de trabalho do Judiciário. Essas transformações têm sido realizadas essencialmente por meio de mudanças de direito positivo, tanto de origem legislativa, com regras que buscam atribuir um maior poder normativo ao Judiciário, quanto de origem regimental, normas criadas pelo próprio Judiciário, que, desse modo, interpreta e delimita suas próprias competências. A implantação de mudanças institucionais e normativas sem contrapartida de uma cultura de precedentes cria, contudo, uma miríade de problemas práticos, na medida em que se verificam condicionamentos recíprocos entre a efetividade dos arranjos legais e institucionais e o uso que lhes é dado. 
Uma série de fatores que obstaculizam a construção e a aplicação de precedentes consubstanciam-se nos métodos de trabalho e técnicas decisórias típicas da tradição de civil law na qual se funda o sistema jurídico brasileiro, como (i) os procedimentos de deliberação e tomada de decisão nas cortes; (ii) a formulação e estruturação de decisão em votos individuais, que dificulta, ou mesmo impossibilita, a identificação da ratio decidendi do tribunal; (iii) a forma de publicação das decisões e (iv) o amplo acesso ao judiciário, sobretudo ao Supremo Tribunal Federal (STF), o que determina um volume de casos a serem julgados sobre-humano e dificulta o exercício da atividade adjudicatória de forma condizente com preocupações que devem nortear um órgão decisório que não apenas decide a questão em mãos, mas também formula parâmetros decisórios a serem seguidos em casos semelhantes futuros.

De um modo geral, esses fatores, ainda que de ordens diversas, podem ser correlacionados a traços atávicos da cultura de civil law. Desse modo, conquanto mudanças legislativas e institucionais almejem vincular juízes e tribunais a decisões anteriores, tais reformas não alçam o precedente como elemento de organização do sistema jurídico e, por conseqüência, da forma de pensar o direito e dos métodos de tomada de decisão judicial - ou sequer têm esta pretensão -, de sorte que a tão propagada aproximação dos sistemas jurídicos reflete-se apenas em mudanças superficiais. O plano cultural torna-se, assim, condicionante incontornável das reformas promovidas nos planos normativo e institucional. O resultado obtido será, dessa forma, arranjo diverso, porquanto mantida a diferença fundamental entre um modelo de pensar o direito e outro, consubstanciada justamente no papel do precedente em uma tradição que cede lugar à deferência ao direito legislado noutra. Trata-se não apenas da autoridade conferida pelos sistemas aos precedentes e às leis como fonte de razões passíveis de fundamentar uma decisão judicial, mas também na forma como decisões são construídas e justificadas, o que repercute diretamente na operacionalidade de tais mecanismos de vinculação de 
precedentes.

A presente dissertação focar-se-à na descrição das modificações promovidas no sistema constitucional brasileiro desde a promulgação da Constituição Federal de 1988 relacionadas a tentativas de vinculação de juízes e tribunais a decisões anteriores. Abordarei, em seguida, fatores institucionais e culturais condicionantes da efetividade dessas reformas. Buscarei, ainda, testar minha hipótese a partir da análise de dados quantitativos do Judiciário brasileiro, sobretudo do STF. Antes, contudo, da análise dos três eixos do presente trabalho, farei uma descrição pormenorizada do plano de pesquisa que o orientou e aprofundarei os pressupostos teóricos subjacentes ao problema proposto.

\section{II - Proposição do problema e plano de pesquisa}

É afirmação corrente que uma tendência de aproximação dos sistemas jurídicos de tradição de civil law e common law estaria a configurar-se, em razão da progressiva relativização das diferenças propugnadas como caracterizadoras das duas grandes tipologias e sua paulatina insuficiência para descrição e enquadramento dos sistemas de fato existentes. ${ }^{2}$ No que tange aos

2 Nesse sentido, Mauro Capelletti, The judicial process in comparative perspectives, Oxford: Clarendon Press Oxford, 1989, 'The Doctrine of Stare Decisis and the Civil Law: A Fundamental Difference - or no Difference at All?', In: Festschrift für Konrad Zweigert zum 70. Geburstag, Tübingen, J.C.B. Mohr, 1981, Martin Shapiro, Courts, a comparative and 
sistemas conformados pela tradição de civil law, tal propensão revelar-se-ia na reformulação e valorização do papel da jurisprudência, atribuída de crescente autoridade normativa por intermédio de modificações de direito positivo e redesenho institucional do poder judiciário.

O presente estudo insere-se nesse debate, buscando problematizar questões subjacentes à efetividade de reformas procedimentais que almejam a vinculação judicial em relação a decisões anteriores, em contexto institucional e cultural bastante diverso daquele em que se costuma verificar a aplicabilidade da doutrina do stare decisis.

A minha hipótese é a de que, muito embora transformações significativas nos planos institucional e normativo apontem no sentido da expansão do papel da jurisprudência, a ausência de uma cultura de precedentes e as peculiaridades institucionais brasileiras, como a forma de deliberação entre os ministros de nossa corte constitucional e formas de justificação decisória, restariam incólumes. Não que fosse o objetivo produzir modificações que levassem à aproximação com o direito de origem anglo-saxônico, mas se a vinculação de decisões puder ser indicativa de qualquer tendência neste sentido, o contra-argumento que será sustentado ao longo das próximas páginas é o de que essa vinculação, normativamente instituída no sistema jurídico brasileiro, é matizada por fatores culturais e institucionais, de modo que ao final se tem algo inteiramente diverso.

political analysis, Chicago: The University of Chicago Press, 1981. Zweigert e Kötz, 'Lawfinding and procedure in common and civil law', In: Introduction to comparative Law. Jan Kleinheisterkamp, 'Comparative Law in Latin America', In: The Oxford Handbook of Comparative Law. 
Em outras palavras, conquanto a ausência de uma cultura de precedentes tenha sido combatida por mecanismos de vinculação de decisões, uma série de fatores refratários a tais mudanças - uma vez que moldados pela tradição de civil law - foram mantidos, como procedimentos de deliberação e tomada de decisão nas cortes; formulação e estruturação de decisão judiciais; forma de publicização das decisões, sem preocupação de explicitação da ratio decidendi; uso que fazem os agentes que acessam o judiciário dos precedentes aplicáveis às suas demandas, entre outros. Ademais, a própria estrutura institucional do judiciário, progressivamente dotada de mecanismos normativos para vinculação de juízes e cortes inferiores, é evidência da superficialidade de tais mudanças, na medida em que não se espera submissão voluntária à autoridade do precedente da corte superior sem que consequências negativas sejam impostas às decisões em desconformidade.

Desse modo, o atributo de autoridade normativa progressivamente conferido à jurisprudência em sistemas de civil law - e particularmente no sistema jurídico brasileiro, ao qual se restringe a presente pesquisa -, por intermédio de modificações de direito positivo e de organização institucional do poder judiciário, resultariam em arranjo outro, diverso do previamente existente, mas também não assemelhado à prática judiciária dos sistemas de common law, em razão de fatores relacionados à própria forma de pensar e produzir o direito.

Para o enfrentamento desse debate, segmento a exposição em três planos de análise: o normativo, o institucional e o cultural. Ainda que a minha hipótese pressuponha a inter-relação e o condicionamento recíproco dos elementos institucionais, normativos e de cultura jurídica, uma vez que sustento que mudanças circunscritas a um plano não seriam capazes de atingir resultados objetivados sem adaptações nos demais, a execução da presente dissertação implicaria, de uma forma ou outra, a necessidade de alguma 
organização metodológica. Os diversos fatores envolvidos no problema de pesquisa serão assim agrupados nesses três planos, sem que, com isso, se pressuponha qualquer análise estanque. Passemos então a uma breve descrição do que será tratado em cada uma dessas partes.

No plano normativo, pretendo fazer uma descrição objetiva de recentes transformações do sistema jurídico brasileiro relacionadas à incorporação de mecanismos de vinculação de precedentes judiciais. A ausência de uma cultura de precedentes que reconheça formalmente os precedentes judiciais como fonte passível de justificação de uma decisão implica a necessidade de atribuição de autoridade normativa às decisões judiciais por mecanismos de direito positivo, que propiciem vinculação dos juízes e cortes e atribuam consequências à não observância de precedentes. É, pois, nesse plano de análise que, em tese, são definidos (i) os limites do exercício da atividade adjudicatória quando atribuída de efeito vinculante, (ii) os destinatários dos precedentes vinculantes e (iii) as possíveis consequências de sua não observância. $O$ plano normativo consubstancia-se, desta forma, como expressão mais clara de incorporação de elementos que podem ser associados à tradição de common law ${ }^{3}$

\footnotetext{
${ }^{3}$ Nesse sentido, reformas normativas que introduziram a vinculação de precedentes são encontradas na trajetória recente dos países da América Latina como um todo. Em geral, foram problemas de sobrecarga de trabalho do Judiciário que motivaram tais modificações, concebidas de forma autônoma, ou ainda por incentivo de agentes externos, como o Banco Mundial. Ficando apenas com dois exemplos, é possível verificar tendências semelhantes às observadas no Brasil. No México, a Lei Orgânica do Poder Judiciário de 1995 estabeleceu a possibilidade de o Pleno e as Salas da Suprema Corte, além do Tribunal Eleitoral, decidirem questões jurídicas em caráter vinculante. Ademais, uma recente alteração na Lei de Amparo introduziu requisitos formais e materiais para o estabelecimento da jurisprudência, além de ter incluído um procedimento específico para a revisão das decisões vinculantes anteriores (uma espécie de overrulling). Foi ainda criada a possibilidade dos tribunais de circuito criarem
} 
No plano institucional, o desenho institucional do Poder Judiciário, a dinâmica da sua relação com os demais poderes e instituições sociais e, ainda, a auto-compreensão do Judiciário acerca de suas competências e atribuições são fatores determinantes para a efetividade dos mecanismos normativos de vinculação de decisões judiciais. Dado o fôlego do presente trabalho e alta complexidade do arranjo institucional do judiciário brasileiro, restrinjo a análise, nesse ponto, ao STF, no papel de formulador de precedentes possivelmente vinculantes.

Ainda sobre a dinâmica institucional, questões relacionadas à possibilidade de o Judiciário selecionar os casos que julgará e quais poderão resultar em precedentes vinculantes são fatores de extremo relevo, na medida em que a quantidade de casos julgados pelas cortes superiores, sobretudo o STF, é ainda muito elevada, diferindo da quantidade diminuta de casos julgados pelas cortes de países de common law. Como argumentarei adiante, uma das principais diferenças entre o raciocínio jurídico desenvolvido em decisões judiciais do common law e do civil law é justamente a cuidadosa análise prospectiva acerca da aptidão da decisão que está sendo formulada para servir como fonte de razões e parâmetro de julgamento em casos futuros, algo deveras complicado de ser feito em cortes que julgam centenas de milhares de casos ao ano.

precedentes vinculantes para os demais órgãos judiciários hierarquicamente inferiores sempre que uma determinada questão jurídica for decidida de forma unânime por cinco vezes consecutivas. No Peru, por sua vez, as decisões da Corte Constitucional Peruana tornaram-se vinculantes em sede de controle de constitucionalidade difuso e concentrado. Posteriormente, uma modificação no Código de Procedimento Penal garantiu a possibilidade de criação de precedentes vinculantes em material penal (nas Salas Penales da Corte Suprema nos Plenos Jurisdiccionales) e, então, em questões de direito civil. 
Também a análise do modelo de deliberação e tomada de decisão que é realizado nas cortes será interessante para a verificação da viabilidade de tal análise prospectiva, na medida em que diametralmente oposto àquele consolidado na tradição de common law. Como os julgamentos colegiados nas cortes se realizam pela soma de uma pluralidade de votos - individualmente proferidos e publicados -, uma mesma decisão pode contar com rationes diversas, possivelmente uma para cada um dos julgadores ainda que haja convergência na decisão final. Argumento que tal procedimento seria, em si, fator indicativo da ausência de uma cultura de precedentes, na medida em que razões diversas são combinadas de maneira desarticulada e não há explicitação da ratio da corte para a decisão que possivelmente teria de ser aplicada em casos futuros semelhantes. Com efeito, a formulação (e também a publicização) que juízes e cortes devem dar ao que de fato vincula em sua decisão condiciona, inevitavelmente, a forma como os precedentes poderão ser utilizados e em que medida poderão ser vinculantes.

Por fim, no tocante à cultura jurídica, a compreensão da forma como estão sendo implementados mecanismos normativos e institucionais voltados à vinculação de decisões judiciais passa, necessariamente, pela análise da cultura jurídica de um país. Com efeito, o uso que agentes sociais e econômicos fazem desses mecanismos e a receptividade do Judiciário quanto à formulação e à aplicação de precedentes vinculantes determinarão, inexoravelmente, a efetividade desses novos arranjos.

Conquanto uma miríade de fatores possa ser analisada nos planos institucional e normativo, deve-se ter em conta que as instituições e as normas inserem-se em um contexto histórico, cultural, político e socioeconômico, com implicações decisivas na operacionalidade de ambos. O melhor texto legal, ou melhor arranjo institucional, nunca funcionará bem se os seus aplicadores não estiverem dispostos a dar-lhe efetividade; por outro lado, um texto 
tecnicamente imperfeito, com lacunas ou inconsistências, ou um desenho institucional insatisfatório podem revelar-se virtuosos na prática, na medida em que os intérpretes e aplicadores do direito estiverem dispostos a utilizá-los de acordo com suas finalidades.

Nesse sentido, a compreensão do próprio judiciário acerca do papel dos precedentes judiciais nos respectivos sistemas é determinante na forma como tais mudanças efetuadas nos planos normativo e institucional serão de fato operacionalizadas. Nesse plano de análise, devo buscar analisar, na medida do possível, como o Judiciário realiza a justificação decisória, de modo a viabilizar-se, ou não, juízo prospectivo na construção de uma decisão, isto é, reflexão sobre os efeitos de sua atividade criativa em casos posteriores a serem julgados por ele ou por órgãos hierarquicamente inferiores.

É pouco provável que a presente dissertação seja exitosa na demonstração de todas as condicionantes à vinculação de decisão e indicação de seu real grau de influência na efetividade das reformas procedimentais voltadas a esse propósito. A desmistificação de vinculação à precedentes e a identificação das variáveis envolvidas, para além da desconstrução de alguns lugares comuns que não se sustentam na narrativa constitucional brasileira contemporânea, são passos que, acredito, poderão garantir alguma consistência ao produto final. Algumas questões serão, entretanto, inevitavelmente legadas para pesquisas subsequentes. 


\section{III - Duas formas distintas de pensar o direito}

Ainda que entendidas como estruturas ideais conformadoras dos sistemas jurídicos em geral, nem sempre muito precisas na descrição dos modelos de fato existentes, o cotejo das características gerais dos sistemas que se consolidaram a partir das tradições de common law e civil law, particularmente das formas de estruturação e justificação decisória, permite a derivação de relações de causalidade salutares para análise dos resultados das mudanças institucionais e normativas introduzidas no sistema brasileiro com vistas à vinculação de decisões judiciais. Antes, portanto, de passar a descrição do caso brasileiro, cumpre-nos desenvolver alguns subsídios teóricos atinentes à hipótese de pesquisa.

Sendo o direito uma prática social interpretativa, que não apenas regula interações entre agentes e instituições sociais, mas também consubstancia valores compartilhados socialmente, pode-se dizer que ele reflete as tradições, a história e a evolução da própria sociedade em que se insere. A contraposição das tradições de civil law e common law consideradas aqui, reitero, como estruturas generalizantes conformadoras dos sistemas jurídicos em geral, mais ou menos exatas nas concretizações específicas - seria a comparação de duas práticas sociais distintas, ancoradas em uma evolução histórica de valores diversos. ${ }^{4}$

Enquanto o common law seria, essencialmente, uma tradição jurídica fundada no costume (mas não qualquer costume, e, sim, aquele reconhecido

\footnotetext{
${ }^{4}$ Vide, entre outros, Ronald Dworkin, Justice for Hedgehogs (2011).
} 
pelas órgãos responsáveis como fonte dotada de autoridade, o que remete à ideia de precedente); as principais fontes do civil law seriam os textos legislativos codificados. Para além da diferença de estrutura e formulação das fontes do direito, uma feita com base em casos concretos, e a outra em regras abstratas, deve-se ter em conta as diferenças no raciocínio jurídico que se condensaram nas práticas de uma ou outra tradição.

O texto de uma decisão judicial, que consubstancia a mais precisa demonstração do raciocínio jurídico em operação, isto é, de aplicação do direito a casos concretos, explicita as diferenças mais patentes entre as formas de pensar o direito do common law e do civil law. Apesar de semelhantes na essência, particularmente quanto à necessidade de subsunção de um fato a uma hipótese normativa e, então, de aplicação das consequências previstas nesta às partes envolvidas, as formas de redação e justificação de decisões judiciais são substancialmente diversas.

Caricaturalmente, enquanto a tradição de civil law estaria baseada numa forma de pensar o direito baseada no racionalismo e numa metodologia dedutiva, ambos apoiados em silogismos e na conceitualização sistemática de institutos jurídicos, categorias estruturantes do direito de inspiração romanística; o common law, por sua vez, estaria fundado no empirismo e numa metodologia indutiva. Em suma, enquanto as decisões judiciais na tradição de common law seriam argumentativas, discursivas e casuísticas; as decisões de civil law seriam construídas com base em silogismos baseados na aplicação de regras e princípios extraídos de textos legislativos. Ainda que tais diferenças pareçam apontar apenas para a forma de estruturação das fontes passíveis de fundamentação de uma decisão judicial, a atribuição de autoridade às decisões judiciais que existe em uma tradição e inexiste noutra é determinante na formulação das próprias decisões, na medida em que revela preocupações diversas de justificação decisória. 
Sobre o método de construção de decisões judiciais no common law, Zweigert e Kötz afirmam:

"A técnica do juiz do common law de abordar o case-law e extrair dele regras e princípios é produto de uma tradição madura e experimental de argumentar de caso a caso. O juiz anglo-americano inicia seu processo de decisão com precedentes individuais que os advogados das partes tenham argumentado serem os mais diretamente aplicáveis à questão. Nesses precedentes, ele reconhece certas 'regras', isto é, soluções de problemas atuais particulares. Ele observa como essas 'regras' foram historicamente limitadas, estendidas e refinadas por outros 'precedentes' e então, mantendo, constantemente, esses problemas práticos em mente, gradualmente extrai deles 'princípios' e 'parâmetros' de nível superior que ele usa para formular e testar hipóteses de resolução do caso diante de si; ele, então, verifica a adequação dessas hipóteses em face de casos semelhantes e, finalmente, chega a decisão em si. Todos esses passos são seguidos discursivamente: argumentos pró e contra são apresentados e refutados diante de casos reais ou imaginários"

A descrição dos autores parece impensável de materializar-se em uma decisão judicial proferida em um sistema de tradição civilista. Ainda que decisões prévias sejam evocadas na argumentação jurídica de uma decisão judicial, o são geralmente apenas se corroborarem um determinado argumento que conduzirá a solução desejada, baseada, em regra, na aplicação de uma norma extraída de um texto legislativo, de sorte que precedentes contrários

\footnotetext{
${ }^{5}$ Tradução livre. Zweigert e Kötz, An introduction to comparative law, 3rd Ed, Oxford: Oxford University Press, 1977, p. 263.
} 
acabam ignorados tanto pelas partes que acessam o judiciário, quanto pelos próprios juízes na justificação de suas decisões, uma vez que não há qualquer regra que lhes imponha a obrigação de justificar a não aplicação de uma solução diversa construída em um caso prévio semelhante.

O contraste da forma de raciocínio jurídico indutiva e dedutiva ganha relevo na medida em que os silogismos dedutivos do jurista de civil law determinam um caminho argumentativo que vai de princípios gerais a regras específicas que conformarão a decisão do caso em questão e apenas isso; ao passo que a indução do common law move-se de regras previamente formuladas em casos pretéritos a princípios gerais que fundamentarão a presente decisão e poderão ser utilizados em casos semelhantes futuros, de vez que o resultado final desse raciocínio deve conter não apenas a decisão daquele caso específico, mas também as razões que conformaram a regra aplicável àquele caso e que deverão ser levadas em conta na aplicação deste precedente.

Essa consequência do empirismo indutivo do common law, que parte da aplicação de precedentes anteriores para a construção de precedentes para casos futuros, é uma diferença salutar na compreensão de como diferem ambas tradições jurídicas. O juiz, ao julgar um caso, dialoga não apenas com casos passados com alguma margem de semelhança, mas também com casos futuros, na medida em que deve explicitar as exatas razões pelas quais aplicou ou deixou de aplicar um precedente. Posteriormente, estas razões deverão ser ponderadas na decisão de um caso futuro que o tome como precedente.

Estabelecem-se, portanto, dois diálogos, um com passado, a fim de que se verifique a existência de precedentes judiciais que vinculam o tribunal, e um com futuro, na medida em que a decisão tomada pela corte deve servir como parâmetro de decisões subsequentes. Levando ao extremo tais conseqüências, Goodhart asseverou que o juiz do common law seria um escravo do passado e um déspota do futuro, constrangido por limitações 
impostas por gerações que lhe precederam e constrangedor das gerações do por vir. ${ }^{6}$ Segundo esse autor, a doutrina do precedente vinculante seria a distinção fundamental entre o método jurídico inglês e o continental-europeu, e não o caráter codificado e sistematizado do direito continental e a fragmentação do direito anglo-saxônico. Isso porque, mesmo que houvesse um esforço de sistematização da legislação e dos precedentes em países de tradição de common law, remanesceria a diferença estrutural, a radicar na formulação das decisões judiciais, que decidem não apenas o caso presente, mas também legam regras decisórias a serem aplicadas em casos futuros semelhantes (a não ser que o próximo julgador desincumba-se do ônus argumentativo necessário para o afastamento ou a superação de tal precedente).

Conquanto muito se fale no caráter arraigado à história e à tradição do common law", o "diálogo com o futuro" parece-me igualmente fundamental na comparação das duas tradições, de vez que ausente de todo na atividade adjudicatória no civil law. É esse olhar prospectivo dos juízes de common law que permite uma aplicação coerente de precedentes judiciais, uma vez que há uma preocupação de explicitação clara das razões pelas quais se tomou determinada decisão e se construiu determinado precedente, para que essas

\footnotetext{
${ }^{6}$ Precedent in English and Continental Law - An Inaugural Lecture before the University of Oxford. London: Stevens and Sons. Apud: Thomas Bustamante, Uma teoria normativa do precedente judicial - O peso da jurisprudência na argumentação jurídica, Tese de Doutoramento, 2007.

${ }^{7}$ E na problemática adaptação a problemas atuais, que poderia ser endereçada de forma mais célere por uma autoridade legislativa. Nesse sentido, ver, por exemplo, S. Waddams, The dimensions of private Law (2003), P. Weinrib, The idea of private law (1995).
} 
razões possam ser consideradas em casos posteriores que guardem alguma margem de semelhança. Somente dessa forma é possível efetivo cotejo da ratio decidendi do precedente anterior com as particularidades do caso presente para determinação da aplicabilidade da regra contida no primeiro ou estabelecimento da razão pela qual é inaplicável, de modo que, progressivamente, se construa uma jurisprudência uniforme e coerente.

A simples preocupação com a criação de mecanismos de vinculação de decisões, no plano do direito positivo, sem a incorporação de técnicas decisórias voltadas a uma construção sistemática de precedentes, isto é, sem que se desenvolva uma metodologia de raciocínio jurídico que implique a explicitação da ratio decidendi, com todas as mediações argumentativas que determinam a subsunção fática a uma determinada regra específica formulada pelo juiz para solução daquele caso, dificilmente será possível atingir resultados satisfatórios no que concerne à uniformização da jurisprudência.

Embora se possa considerar que mecanismos de direito positivo que determinam a vinculação de cortes e juízes aos precedentes possam, em alguma medida, relativizar gradativamente as diferenças entre ambas tradições jurídicas, na medida em que decisões judiciais tornam-se passíveis de constituir razões dotadas de autoridade suficiente para a justificação de outras decisões, as técnicas interpretativas e os métodos de aplicação de tais precedentes por juristas anglo-saxões e aqueles de tradição romano-germânica continuarão a divergir.

Diversa é a posição de Thomaz Bustamante, que afirma que não haveria grandes diferenças nas formas de pensar o direito do common law e do civil law. Segundo o autor:

Ainda que se reconheça um grau maior ou menor de liberdade do juiz no common law e no civil law, é evidente que o tipo de processo 
mental realizado pelo juiz ao criar regras individuais com fundamento em regras gerais é qualitativamente o mesmo, e o juiz está metodologicamente livre para decidir como the aprouver (dentro dos limites do direito preexistente). Do ponto de vista teórico, não parece haver grande diferença entre o processo de produção do direito jurisprudencial no civil law e no common law. Para o positivismo jurídico - que, embora decadente, ainda é o pano de fundo das duas tradições jurídicas - em ambos os casos o juiz é metodologicamente livre e sua atividade consiste em um ato de criação normativa com fundamento nas normas gerais do ordenamento em que a decisão se insere. O processo de raciocínio, como a análise de Kelsen permite crer, é o mesmo nas duas tradições jurídicas. O direito judicial embora tenha vinculatividade ou força diferente nas duas tradições se forma do mesmo modo ${ }^{8}$.

Ao sustentar que há espaço para a criatividade judicial em ambos sistemas, de vez que, independente da fonte de onde se extrai a norma aplicável, haverá sempre alguma margem de liberdade na subsunção da fato à norma, a posição de Bustamante - desenvolvida em uma análise normativa sobre regras universais de aplicação de precedentes - funda-se na ausência de diferença estrutural no ato de subsunção de uma fonte ou outra. Mas ainda que o tipo de processo mental realizado pelo juiz ao criar regras individuais com fundamento em regras gerais seja qualitativamente o mesmo, isso não descaracteriza o fato de serem diversas as formas de justificação e formulação de decisões a formalizar tal processo em uma ou outra tradição, o que será determinante na forma como uma decisão será construída e poderá ser utilizada em casos futuros como precedente dotado de autoridade, determinando, assim,

\footnotetext{
${ }^{8}$ Idem, p. 25.
} 
um ônus argumentativo de aplicar ou não sua ratio decidendi. Em outras palavras, a possibilidade de exercício de algum grau de criatividade por parte de juiz na fundamentação decisória, seja ela baseada em precedentes ou em textos legislativos, sustentada por Bustamante, não dilui a diferença estruturante no raciocínio jurídico desenvolvido em decisões judiciais no common law e no civil law no que tange à forma de construção das decisões judiciais, que inclui, no primeiro caso, não apenas a extração de regras decisórias de casos passados, mas também uma análise prospectiva acerca da aplicabilidade futura do precedente que se está a construir. Desse modo, mantém-se diferença salutar na forma como o direito judicial será desenvolvido, interpretado e aplicado.

Em verdade, a polêmica em torno da criatividade judicial já resta aplacada em ambas as tradições, de vez que reconhecido o potencial criativo da atividade interpretativa seja ela embasada em códigos escritos, seja ela em precedentes judiciais. Independente de quais forem as fontes aplicáveis, uma decisão judicial não pode ser compreendida como simples aplicação mecânica de regras previamente existentes, de vez que há inevitável processo de interpretação normativa e, dessa forma, de criação de significados. Se, no common law, a criatividade judicial já é vista há muito como uma discricionariedade regrada; conquanto potencialmente criativa com relação ao futuro, é estritamente confinada nos interstícios das possibilidades legais depreendidas de fontes de direito previamente existentes ${ }^{9}$. No civil law,

\footnotetext{
${ }^{9}$ Nesse sentido, Julius Stone afirma: "the availability of judicial choices is not the same as to assert judicial arbitrariness in decision, or even judicial "legislative power" in the sense in which we attribute this to the legislature. The effect of the exercise of the judicial duty to choose is, of course, to produce new law and control and guide its growth; in this sense it may be called 'creative' or even 'legislative'. But unlike that of the parliamentary legislator, the judicial choice is usually between alternative decisions and modes of reaching them presented
} 
igualmente, não há como se falar em vinculação total dos juízes por códigos legais. Como afirma Martin Shapiro:

A code law judge would be most completely bound by preexisting rules if his code were complete, consistent, specific, produced by a single authoritative legislator, and capable of rapid amendment by that legislator to meet changing circumstances accurately. No code can fully meet these conditions ${ }^{10}$.

No common law, ainda que precedentes limitem as possibilidades decisórias de um juiz, a interpretação de decisões pretéritas e a argumentação com vistas à sua aplicação, afastamento ou superação são inegavelmente atividades criativas. $\mathrm{O}$ debate mesmo sobre a identificação da ratio decidendi é ilustrativo do papel criativo do juiz que define o que foi determinante na construção de uma decisão tomada como precedente. Remonta à década de 1930, a tese de Goodhart, contrária à prática então prevalecente, que sustentou que, diante de um precedente, o intérprete deveria averiguar quais seriam os fatos relevantes para a tomada de decisão, de modo que pudesse então cotejálos com os fatos diante de si no caso presente. Sua tese tornar-se-ia célebre,

to the judge by the authoritative materials of the law. These materials do, of course, include areas of settled rules which it would require parliamentary action to overcome. But they also present (especially at the appellate level) guide posts to alternative solutions which remain legally open, beyond the settled areas. In these senses the required judicial choice-making here under discussion, creative as it is, is still (in Cardozo's famous phrases) confined from molar to molecular motions, and is 'interstitial' in character". Julius Stone, "The Ratio of the Ratio Decidendi”, in Modern Law Review, Volume 22, Issue 6, p. 616

${ }^{10}$ SHAPIRO, Martin, Courts, a comparative and political analysis, Chicago: The University of Chicago Press, 1981, p. 126. 
influenciando a academia e a prática jurídica nos países de common law. Seria questionada décadas mais tarde pelo professor da Universidade de Sydney, Julius Stone, dentre outros. Stone defendeu que o papel do intérprete seria de reconstrução da decisão a partir de fatos escolhidos como relevantes tendo em vista o caso a ser decidido. Não se afastaria, assim, a aplicabilidade de um precedente se identificados como os mais relevantes para a decisão fatos diversos daqueles analisados no caso atual. Bastaria haver fatos assemelhados, para que fosse possível identificar, no raciocínio jurídico desenvolvido no precedente, o impacto deles em sua condução. Permitir-se-ia, desse modo, a identificação de uma pluralidade de rationes decidendi em cada precedente, em função das diferentes combinações factuais que poderiam ser extraídas em cada situação posterior $^{11}$.

Sendo uma ou várias as rationes decidendi possivelmente extraíveis de um caso, é importante notar que essa operação implica uma atitude

11 Nesse trecho, Julius Stone apresenta, com clareza, a tese de Goodhart e seu contraargumento: "The ratio decidendi" of that case, may also be an intellectually impermissible activity, unless at least two assumptions can be made. One of these is that there is normally ONE ratio decidendi, AND ONE ONLY, which explains the holding on the facts, and is as such binding. The other is that such a ratio decidendi, assumed to exist, can be delimited from examination of the particular case itself. Professor Goodhart's paper of 1981 (originally published 1980), "“ both by its general thesis and by its detailed argument, indulges both of these assumptions.' (...) If the ratio of a case is deemed to turn on the facts in relation to the holding, and nine facts (a)-(j)are to be found in the report, there may (so far as logical possibilities are concerned)be as many rival rationes decidendi as there are possible combinations of distinguishable facts in it. What is more, each of these facts " is usually itself capable of being stated at various levels of generality, all of which embrace "the fact" in question in the precedent decision, but each of which may yield a different result in the different fact- situation of a later case. Julius Stone, "The Ratio of the Ratio Decidendi", in Modern Law Review, Volume 22, Issue 6, p. 602 e 603/608. 
interpretativa que seja capaz de compreender os caminhos trilhados na decisão anterior. Implica, ainda, que a formulação decisória do precedente tenha sido racionalmente construída, de modo que seja possível reproduzir esses caminhos trilhados e as razões que os motivaram. A preocupação do juiz que aplica um precedente consiste, assim, em extrair razões decisórias, e não apenas um dispositivo final. Como veremos ao analisar os mecanismos normativos de vinculação de decisões no direito brasileiro, nenhuma dessas operações foi tornada viável quando da formulação das reformas procedimentais que os introduziram ou tomadas em consideração quando da sua aplicação.

Outro argumento que deve ser abordado acerca da aplicabilidade universal dos precedentes é sustentado por MacCormick e Summers. Consideram os autores que a adesão ao precedente constitui uma operação básica da racionalidade, uma vez que aplicar lições do passado para solucionar problemas presentes e futuros é um elemento básico da razão prática humana $^{12}{ }^{13}$. A diferença, contudo, na valoração do precedente como fonte de autoridade por cada sistema jurídico influi, contudo, na postura do

\footnotetext{
${ }^{12}$ MacCormick; Summers, Interpreting Precedents (1997), p. 1 e ss.

${ }^{13}$ No mesmo sentido, também Frederik Schauer argumenta: appeals to precedent do not reside exclusively in courts of law. Forms of argument that may be concentrated in the legal system are rarely isolated there, and the argument from precedent is a prime example of the nonexclusivity of what used to be called "legal reasoning." Think of the child who insists that he should not have to wear short pants to school because his older brother was allowed to wear long pants when he was seven. Or think of the bureaucrat who responds to the supplicant for special consideration by saying that "we've never done it that way before." In countless instances, out of law as well as in, the fact that something was done before provides, by itself, a reason for doing it that way again. (grifos meus). "Precedent", Stanford Law Review 39 (1987), p. 572.
} 
julgador diante de um caso. Juízes de common law têm consciência de que cada decisão por eles tomada estará contribuindo para o desenvolvimento do direito, na medida em que serão definidos parâmetros decisórios para casos semelhantes futuros. Por essa razão, sistemas jurídicos que dotam precedentes judiciais de autoridade normativa imporiam aos seus juízes e suas cortes não só a adoção de um backward-looking, no que tange à averiguação de casos semelhantes julgados previamente, como também de um forward-looking ${ }^{14}$ :

"Em razão da própria existência de uma prática de atribuir autoridade a decisões passadas, aquele que se engaja na decisão de um novo caso o faz sabendo que a decisão alcançada ao final será ela própria tomada como guia em casos posteriores. Essa consciência define um teste importante para a solidez da presente decisão: será ela satisfatória como um precedente? Os juízes são conscientes de que suas decisões contribuirão para o desenvolvimento do direito e, portanto, têm em conta questões de política pública e de princípio quando formulam suas decisões".

Ainda que o aprendizado com experiências passadas seja apontado pelos autores como operação básica da racionalidade humana, a atividade judicial de retomada de precedentes é apresentada pelos autores como atividade criativa consciente. O juiz decide o caso com o cuidado de demonstrar o raciocínio jurídico aplicado e os fatos materiais que o encaminharam, para que se possa, posteriormente, extrair regras de sua decisão, a serem, então, aplicáveis a casos sucedâneos. Ademais, questões de política pública são necessariamente consideradas, na medida em que, ao formular uma regra

\footnotetext{
${ }^{14}$ Idem, p. 2.
} 
potencialmente aplicável em outros casos, o juiz deve considerar tanto os impactos de sua decisão para as partes envolvidas quanto os efeitos futuros de sua reprodução em casos semelhantes. Desenvolve, assim, uma análise de maior alcance, que não pode prender-se unicamente ao caso que está sendo decidido.

O "forward-looking" implica, portanto, não apenas o cuidado na explicitação racional dos motivos jurídicos e factuais que embasaram uma decisão, afim de que ela possa ser replicada posteriormente, mas também a consideração dos macro-efeitos dessa decisão, quando reproduzida em casos análogos. O debate contemporâneo sobre a judicialização de políticas públicas no Brasil, preocupado com os impactos de decisões judiciais que revertem escolhas políticas e desconstroem políticas públicas, é indicativo da ausência dessa forma de raciocínio pelos juízes brasileiros ${ }^{15}$.

No tocante ao "backward looking", o juiz, no common law, estaria interessado em extrair regras gerais dos precedentes que guardam semelhança com o caso que decide. Não se trata de mera aplicação do dispositivo final da decisão, mas de reprodução do raciocínio jurídico desenvolvido, de modo a se extrair a razão pela qual se caminhou no sentido de uma decisão ou outra.

Muito embora se verifique, de um modo geral, na jurisprudência pátria uma maior preocupação de citação de precedentes anteriores e uniformização de posicionamentos, a simples evocação de precedentes anteriores favoráveis a

\footnotetext{
${ }^{15}$ Ver, por exemplo, Diogo R. Coutinho, Direito, desenvolvimento e desigualdade: a dimensão jurídica das políticas sociais, São Paulo: Faculdade de Direito da Universidade de São Paulo, Tese de livre docência, 2010; e Marcos Paulo Veríssimo, A judicialização dos conflitos de justiça distributiva no Brasil: O processo judicial no pós-1988, São Paulo: Faculdade de Direito da Universidade de São Paulo, Tese de doutoramento, 2006.
} 
decisão que se quer ver tomada não garante a reprodução desse "backward looking". A mera citação de decisões a corroborar determinado argumento trazido pelas partes ou aduzido pelos julgadores não é equiparável à tomada de decisão mediante aplicação de decisão anteriores, caso em que se pressupõe que seja atribuível autoridade ao precedente judicial.

Nesse sentido, Michel Troper e Christophe Grzegorczyk descrevem as recentes transformações na atividade da corte de cassação francesa no sentido de ampliação do papel dos precedentes como algo restrito ao plano do que é dito nas decisões, impenetrável, contudo, no plano do que de fato é feito, uma vez que ainda não se aceita o papel dos precedentes na justificação de decisões judiciais $^{16}$. Ou seja, cita-se cada vez mais precedentes judiciais, mas as decisões continuam a ser definidas pela aplicação estrita de regras jurídicas extraídas de textos legislativos, de modo que a citação do precedente tem, no máximo, função de legitimação do juiz perante seus pares e, em regra, função meramente retórica na justificação decisória.

As graduações formuladas por Aleksander Peczenik entre precedentes com vinculação formal e a precedentes com mero valor ilustrativo, ou por Aulis Aarnio, de precedentes como must-sources (fontes vinculantes em sentido forte), should-sources (fontes obrigatórias em sentido frágil) ou permissive sources (fontes do direito "meramente permitidas") são úteis para diferenciação entre casos de uso retórico de precedentes ou efetivo papel na justificação decisória. Segundo Peczenik, de um lado, haveria vinculação formal quando uma decisão que não observa um precedente seria ilegal por essa razão, de modo que esse primeiro conceito não comportaria graduação ${ }^{17}$.

\footnotetext{
16 Idem, p. 137 e ss.

${ }^{17}$ Ele compara a ideia de vinculação com a de gravidez. No formulário respondido pelos diversos autores da obra, essa categoria era definida como: “formal bindingness: a judgement
} 
No extremo oposto, estariam os precedentes valorados como mera ilustração da argumentação jurídica, cuja não aplicabilidade não implicaria vício à decisão tomada posteriormente e a citação seria realizada tão somente para demonstrar a coerência diacrônica ${ }^{18}$.

Ainda que na prática ordinária de juízes e tribunais brasileiros, o valor do precedente se enquadre no extremo de mera ilustração na argumentação judicial ou ainda de "permissive sources", os mecanismos normativos que serão analisados no próximo capítulo podem ser considerados como tentativas de alçá-los ao extremo oposto, de estrita vinculação formal ou "must-sources". A formulação e justificação decisória, todavia, continuam da mesma forma, de sorte que, conquanto normativamente dotados de autoridade - como no caso das súmulas vinculantes ou das decisões em controle abstrato de constitucionalidade - os precedentes são citados sem que haja preocupação

not respecting a precedent's bindingness is not lawful and so is subject to reversal on appeal", “The binding force of precedent”, p. 461 a 479, In: Interpreting Precedents, Robert Summers e Neil MacCormick (org), 1997.

18 Outro defensor da gradação entre diferentes formas de vinculação a precedente é, novamente, Frederik Schauer, segundo ele: There is a difference between precedential constraint and total freedom to decide this case in the optimal way, even if the two processes rarely appear in pure form. Yet, by seeing that there is a difference, we see that the extent of reliance on precedent is not fixed, but is subject to change in the same ways as are norms governing any decision making institution. This process does not necessarily depend upon written rules, but reflects the entire array of methods by which decision-makers assimilate what it is proper to do and what is discouraged. "Precedent", Stanford Law Review 39 (1987): $571-605$. 
com suas razões de decidir. Daí a necessidade de que tais mecanismos demandassem tão somente a verificação do comando final da decisão, sem que fosse necessário grande esforço interpretativo por parte do juiz que o aplicará posteriormente. 


\section{Positivação de mecanismos de vinculação judicial em sistema civil law}

A ideia da vinculação aos precedentes judiciais constitucionais surgiu no Brasil com a Emenda Constitucional n. 3 de 1993, que conferiu nova redação ao artigo 102 da Constituição, atribuindo às decisões definitivas de mérito em sede de ação declaratória de inconstitucionalidade (ADI) efeito vinculante e eficácia contra todos.

Criou, ainda, a ação declaratória de constitucionalidade (ADC) com os mesmos efeitos que a anterior. Rogério Arantes e Claudio Couto notam que curiosamente foi a mesma emenda que introduziu diversas modificações de política econômica e tributária em um momento em que o Judiciário estava abarrotado de ações relacionadas à inconstitucionalidade dos planos econômicos de estabilização da inflação ${ }^{19}$. A ADC vinha, assim, ao encontro das urgentes necessidades da fazenda - de reduzir o rombo financeiro causado pela revisão judicial dos planos contra a inflação - e do próprio judiciário - de conter a entrada massiva de causas repetitivas acerca da constitucionalidade das medidas econômicas governamentais. Garantia-se, desse modo, papel de maior destaque ao STF mediante uma ação que, ao fim e ao cabo, poderia servir como instrumento de coordenação do Judiciário e do Executivo, para além da redução da sobrecarga de trabalho do Judiciário.

A extensão dos efeitos vinculantes e gerais das decisões do STF não pararia por aí. Em 1999, com a regulamentação da ADI pela lei federal n. 9.868

\footnotetext{
${ }^{19}$ Rogério Arantes e Cláúdio Couto, "Porque muda e como muda a constituição? Problemas de controle sobre a agenda governamental.", 32o Encontro Anual da ANPOCS, set/2008.
} 
atribuiu-se efeito semelhante aos casos de interpretação conforme à Constituição e de declaração parcial de inconstitucionalidade sem redução de texto $^{20}$. No mesmo ano, com a regulamentação da ADPF pela lei federal n. 9.882, garantiu-se ao STF que, em todas as ações constitucionais, fosse possível a modulação dos efeitos vinculantes e erga omnes quando a Corte se defrontasse com questões de segurança jurídica ou de excepcional interesse social $^{21}$.

A Emenda Constitucional n. 45 de 2004, responsável pela reforma do Judiciário, trouxe ainda maiores mudanças quanto à introdução de mecanismos voltados à vinculação de decisões do STF. Ao consagrar como direito fundamental a razoável duração do processo $^{22}$, tornou-se imperativa a ampla reestruturação do sistema judiciário dado o alto grau de congestionamento de processos e a consequente demora nos provimentos judiciais.

Algumas modificações introduzidas pela emenda no processo decisório do STF, sobretudo mecanismos de vinculação de decisões do STF, seriam salutares nesse sentido. Dentre elas, houve a ampliação do rol de destinatários dos efeitos vinculantes das decisões do STF em sede de controle abstrato de

\footnotetext{
${ }^{20}$ Conforme redação do art. 28, Parágrafo único: A declaração de constitucionalidade ou de inconstitucionalidade, inclusive a interpretação conforme a Constituição e a declaração parcial de inconstitucionalidade sem redução de texto, têm eficácia contra todos e efeito vinculante em relação aos órgãos do Poder Judiciário e à Administração Pública federal, estadual e municipal.

${ }^{21}$ Art. 11 da lei 9882 e art. 27 da lei 9868.

${ }^{22}$ Art. $5^{\circ}$ LXXVIII: a todos, no âmbito judicial e administrativo, são assegurados a razoável duração do processo e os meios que garantam a celeridade de sua tramitação.
} 
constitucionalidade, a introdução do requisito de repercussão geral para admissão de recursos extraordinários e a criação da súmula vinculante ${ }^{23}$. Vejamos então cada uma dessas modificações.

\section{1. Vinculação de decisões em sede de controle abstrato de constitucionalidade}

No que tange ao rol de destinatários dos efeitos vinculantes, é importante notar que, desde 2004, ficaram adstritos às decisões do STF em sede de controle abstrato de constitucionalidade todos os demais órgãos do Poder Judiciário e a administração pública direta e indireta, nas esferas federal, estadual e municipal. Isso significa que, ao menos em sede de ADI e ADC, as decisões do STF são inquestionavelmente vinculantes para todos os órgãos públicos, à exceção do Legislativo ${ }^{24}$.

Declarada a inconstitucionalidade de ato normativo federal ou estadual pelo STF, os demais órgãos judiciários não poderão mais aplicá-lo ou, se

\footnotetext{
${ }^{23}$ Respectivamente, art. $102, \S 2^{\circ}$ e $\$ 3^{\circ}$ e art. $103-\mathrm{A}$.

${ }^{24}$ O Legislativo, contudo, não teria ainda assim a última palavra, de vez que novo ato normativo poderia ter sua constitucionalidade novamente impugnada perante o STF. Esse foi o caso, por exemplo, da ADI 3685-8 que versava sobre novo ato normativo de mesmo conteúdo daquele que foi declarado inconstitucional na ADI 2626 e 2628, ainda que sob nova roupagem formal, da segunda vez como emenda constitucional.
} 
constitucional, não poderão mais afastá-lo sob o argumento de inconstitucionalidade. Considerando o modelo misto de controle de constitucionalidade adotado no Brasil, em que se conjuga o controle abstrato realizado pelo STF ao controle difuso, passível de ser exercido por qualquer juiz ou tribunal, a vinculação das decisões do STF é indispensável para segurança jurídica do sistema, na medida em que resolvida a questão pela mais alta corte do país, impede-se solução diversa em casos pendentes em outras instâncias.

No caso da arguição de descumprimento de preceito fundamental (ADPF), empregada em situação em que inadmitidas as demais ações de controle abstrato, como, por exemplo, o questionamento da constitucionalidade de leis municipais ou leis anteriores a atual ordem constitucional, os efeitos ficam restritos ao Poder Judiciário. É o suficiente, contudo, para evitar que lei promulgada sob a égide de constituição anterior seja considerada recepcionada por algum juízo e não recepcionada por outro.

Tendo em vista a declaração de nulidade do ato normativo questionado que esse tipo de decisão encerra, a norma inconstitucional, em tese, não poderia ter produzido qualquer efeito. Há, entretanto, a possibilidade de o STF ressalvar efeitos pretéritos ou mesmo futuros de acordo com as necessidades relacionadas à segurança jurídica ou a interesses sociais, situação em que poderá haver modulação de efeitos por decisão de maioria de dois terços. Garante-se, desse modo, mais uma forma de o STF não apenas ser responsável pelo resguardo da Constituição, mas também pela proteção do interesse público, ainda que de encontro com dispositivos constitucionais.

Cumpre ainda notar o papel das medidas cautelares, igualmente atribuídas de eficácia vinculante e erga omnes tanto em ADI e ADC quanto em ADPF. Concedida a cautelar em uma ADI, torna-se aplicável a legislação anterior; concedida em sede de ADC, suspende-se o julgamento dos processos 
que envolvam a aplicação do ato normativo em todos juízos até julgamento final do $\mathrm{STF}^{25}$.

Para se evitar a dupla análise do caso pelo STF, há a possibilidade de o julgamento de mérito ser submetido ao pleno pelo relator quando da apreciação da cautelar, com base no procedimento abreviado do art. 12 da lei 9.868. Desde 2002, tem havido a predominância desse tipo de julgamento, de modo que o tribunal evita despender esforços desnecessários manifestando-se duas vezes sobre a mesma questão ${ }^{26}$. Como o efeito da liminar é praticamente o mesmo, o cuidado que o Tribunal tem ao conceder ou negar uma cautelar acaba não diferindo do julgamento final. $\mathrm{O}$ art. 12 da Lei 9.868 propicia, assim, maior celeridade no controle de constitucionalidade concentrado.

Para os propósitos do presente trabalho, cumpre notar que as modificações normativas sob a égide da Constituição de 1988 tem promovido crescente vinculação de juízes e tribunais às decisões do STF. O maior poder conferido à Corte garante, ao menos em sede de controle de constitucionalidade, uma experiência no sentido de decidir casos com olhar de longo alcance. Não obstante, deve-se ter em conta dois aspectos fundamentais acerca da diferença entre o que faz o STF e o que se espera de uma corte que siga uma doutrina de stare decisis. A primeira é que as decisões que são

\footnotetext{
${ }^{25}$ Segundo o relatório final de pesquisa do projeto "Judicialização da política e demandas por juridificação: o Judiciário frente aos outros poderes e frente à sociedade" realizada por equipe da Sociedade Brasileira de Direito Público (SBDP), a similaridade dos efeitos da cautelar e do provimento final em sede de ADI implica ampla utilização dessa ferramenta, de sorte que em mais de $90 \%$ das ADI ajuizadas contra ato normativo produzido pelo executivo haja pedido e cerca $84,5 \%$ quando se trata de ato normativo de origem legislativa.

${ }^{26}$ Ver, nesse sentido, o trabalho de Pedro Luiz do Nascimento Filho, Medida cautelar em ação direta de inconstitucionalidade, São Paulo: Sociedade Brasileira de Direito Público, 2007.
} 
atribuídas de efeito vinculante são tomadas em sede de controle abstrato de constitucionalidade. Desse modo, o STF não precisa formular parâmetros decisórios a serem seguidos em casos futuros semelhantes, ainda que haja a possibilidade de nova lei de conteúdo semelhante ser editada pelo legislativo.

No que concerne à vinculação do próprio Judiciário, as decisões do STF em sede de controle abstrato de constitucionalidade inviabilizam resultados diversos em controle difuso, porém, como apenas se declara a inconstitucionalidade de uma lei, é como se houvesse a eliminação do ato normativo impugnado, seja desde a sua promulgação seja a partir de um momento específico decidido pelo tribunal. Desse modo, o que importa é apenas o dispositivo dessa decisão, que determina a cessação dos efeitos da lei declarada inconstitucional, sendo desnecessária, entretanto, a tarefa de se extrair do precedente raciocínios jurídicos potencialmente vinculantes. Somente nos casos em que há interpretação conforme ou declaração parcial de inconstitucionalidade - situação em que o tribunal pode determinar de que modo a lei deverá ser aplicada para ser considerada constitucional -, pode-se falar que haverá vinculação dos demais juízes e tribunais a algo mais complexo que a mera de declaração de (in) constitucionalidade, de vez que os parâmetros definidos na decisão do STF quanto à forma de aplicabilidade da lei impugnada serão igualmente vinculantes.

O segundo ponto é que o efeito de vinculação conferido às decisões do STF não atinge o próprio tribunal. A autonomia do STF em casos futuros é total, mesmo diante de casos com alto grau de semelhança, o STF não tem a obrigação de seguir seus próprios precedentes. Interessante notar nesse sentido que, mesmo em julgamentos de cautelar e mérito de uma mesma ação, cerca de $25 \%$ dos provimentos finais em ações que questionam atos normativos do 
legislativo (a grande maioria dos casos) diferem da posição do tribunal no julgamento da cautelar ${ }^{27}$. $\mathrm{O}$ fato de não precisar se vincular aos próprios precedentes acaba fazendo com que o STF não precise seguir suas próprias linhas de argumentação desenvolvidas em casos anteriores, o que poderia estabilizar expectativas em casos semelhantes futuros e mesmo reduzir as demandas judiciais, ao enviar sinais claros ao legislador acerca dos parâmetros de constitucionalidade considerados pelo tribunal e aos proponentes dessas ações quanto às chances de êxito de suas demandas.

\section{2. Repercussão Geral}

Introduzida como requisito de admissibilidade de recursos extraordinários, agravos de instrumentos e recursos com agravo, a argüição de repercussão geral alterou a sistemática recursal, permitindo ao STF a seleção dos casos julgados de acordo com critérios de relevância econômica, política, social ou jurídica.

O instituto evoca a argüição de relevância, condição de admissibilidade dos recursos extraordinários sob a égide da Constituição de 1967. Introduzida pela Emenda Constitucional n. 7 em 1977, a argüição de relevância foi mantida até o advento da Constituição de 1988, quando então o STF se viu privado da possibilidade de selecionar os casos que julga com base nesses critérios.

\footnotetext{
27 Relatório final de pesquisa do projeto "Judicialização da política e demandas por juridificação: o Judiciário frente aos outros poderes e frente à sociedade", Sociedade Brasileira de Direito Público, pág. 107.
} 
Entrementes, o STF acabou desenvolvendo técnicas outras para reduzir a sobrecarga de trabalho que lhe era imposta, sobretudo por agravos e recursos extraordinários. A elevada diferença entre o número de casos julgados, bastante expressiva para um corte composta por apenas 11 ministros, e de acórdãos publicados sinalizava a efetiva existência de filtros informais, uma vez que não há publicação de acórdão quando há denegação de seguimento ou não conhecimento por decisão monocrática.

Segundo Marcos Paulo Veríssimo, os juízos de admissibilidades funcionariam como espécie de certiorary à brasileira:

não se pode saber se já não estaria sendo praticado informalmente, no tribunal, antes mesmo da Emenda Constitucional n. 45.04, um juízo prévio de relevância dos casos relativos a recursos extraordinários, juízo esse justificado formalmente sob o prisma formal-procedimental da admissibilidade (nesse sentido, decisões de indeferimento liminar fundadas na falta de requisitos formais ou materiais de admissibilidade poderiam estar travestindo, já de algum tempo, juízos materiais de irrelevância, somente autorizados a partir da EC 45). Essa é uma conjectura que pode fazer especial sentido quando se tem em conta a rigidez com que o STF foi construindo ao longo do tempo suas exigências formais e materiais de admissibilidade do recurso extraordinário (por exemplo, quanto às últimas, no que diz respeito ao prequestionamento, ou à noção de interpretação razoável, contida na Súmula 400, ou a todas as matérias tratadas nas Súmulas 283, 284, 356 e 636 , entre outras) $)^{28}$.

\footnotetext{
${ }^{28}$ Marcos Paulo Veríssimo, “A constituição de 1988, vinte anos depois: Suprema Corte e ativismo judicial à brasileira, in Revista Direito GV, São Paulo, vol 4(2), 2008, p.407-440
} 
O instituto da repercussão geral legitimou, desse modo, uma prática já então seguida. Não obstante, os resultados práticos foram bastante significativos, como analisarei no último tópico do presente capítulo. Somada à possibilidade de julgamentos por amostragem, foi possível efetiva redução da sobrecarga de recursos submetidos à apreciação do STF, para além da garantia de uniformização da jurisprudência em casos de controle concreto de constitucionalidade, em que era possível a existência de resultados díspares. Promoveu-se mesmo a racionalização do trabalho de tribunais estaduais e federais, ao se permitir o sobrestamento de feitos repetitivos e a aplicação de provimento único do STF após a decisão de mérito. Vejamos então a sistemática da repercussão geral.

Apesar de inserida pela Emenda Constitucional n. 45 de 2004, a arguição de repercussão geral somente passou a ser exigível em maio de 2007, quando incluída no regimento interno do STF (RISTF), mediante a Emenda Regimental n. 21/07, e após já ter havido sua inserção no Código de Processo Civil com as alterações promovidas pela lei 11.418 de 2006.

Desde então, o tribunal de origem do recurso extraordinário passou a ter de verificar a existência de multiplicidade de recursos que versassem sobre a mesma questão, delimitar a controvérsia e eleger um ou mais representativos, sobrestando os demais. Após o juízo de admissibilidade, os recursos eleitos representativos seriam remetidos ao $\mathrm{STF}$, onde submetidos a nova seleção com a devolução à origem dos restantes.

Selecionados os casos representativos da controvérsia e delimitado o tema, o STF julga a preliminar de repercussão geral de acordo com a disciplina do RISTF (artigo 322 e seguintes) e do Código de Processo Civil (Art. 543-A e 543-B). Julgando inexistente a repercussão geral, todos recursos que versem sobre matéria idêntica são indeferidos liminarmente. Caso contrário, há o sobrestamento de recursos até o julgamento do mérito pelo STF. 
Finalizado o julgamento da corte, os recursos sobrestados são apreciados pelos respectivos tribunais, turmas de uniformização ou recursais, que poderão declará-los prejudicados quando improvidos ou retratar-se no caso de provimento de mérito pelo STF. Cumpre ainda notar que haverá repercussão geral sempre que o recurso impugnar decisão contrária à súmula ou jurisprudência dominante do Tribunal.

O julgamento de irrelevância exige, contudo, concordância de dois terços dos ministros, quórum superior ao necessário para o julgamento de mérito. Considerando que, em 2006, ano de regulamentação do instituto no CPC, foram distribuídos 110.716 agravos de instrumento e recursos extraordinários, a implementação do mecanismo dependeria de esforços hercúleos dos ministros, reunidos em plenário, para apreciação da relevância de cada um desses casos, tornando praticamente inviável a utilização da repercussão geral sem que se continuasse a aplicar um generoso filtro de admissibilidade pelos relatores antes da submissão ao plenário.

A solução deu-se, então, no regimento interno do Supremo, que criou o chamado plenário virtual, tornando, assim, viável o processamento de uma quantidade fenomenal de arguições de relevância sem a necessidade de reunião para discussão dos casos. Ademais, na própria disciplina processual do mecanismo estabeleceu-se o indeferimento liminar de todos os casos semelhantes, o que garantiu a possibilidade de julgamento por amostragem pelo STF a ser replicado pelos tribunais de origem nos casos semelhantes.

Como veremos ao final deste capítulo, a formalização do filtro de relevância para casos de controle concreto de constitucionalidade submetidos ao STF e a racionalização do trabalho mediante a sistemática desenvolvida não apenas na própria corte como também nos tribunais inferiores permitiu significativa redução da sobrecarga de trabalho do Judiciário, sobretudo do próprio STF. A reprodução de solução única a todos os casos semelhantes 
garantiu ainda a uniformização da jurisprudência da corte suprema, a reafirmar a autoridade de seus julgados e seu papel de resguardo da Constituição.

\section{IV.3. Súmula Vinculante}

Criada igualmente pela Emenda Constitucional n. 45 de 2004, a súmula vinculante tornou possível ao STF a resolução de questões controversas em enunciados abstratamente redigidos após reiteradas decisões sobre assuntos constitucionais.

Remodelou-se, desse modo, as então chamadas súmulas de jurisprudência predominante ou súmulas persuasivas, desprovidas do efeito vinculante do novo instituto. Surgidas por meio de uma alteração no regimento interno do STF proposta pelo Ministro Victor Nunes Leal em 1963, as súmulas tinham como fito "desafogar os trabalhos da corte sobrecarregada de processos" 29 . Tratava-se, portanto, de um instrumento voltado ao incremento da celeridade do método de trabalho do tribunal e à redução do número de julgamentos. Na primeira sessão do tribunal em que súmulas foram criadas, 370 enunciados foram aprovados pelos Ministros do STF, revelando a urgência que o tribunal sentia de um instrumento que pudesse reduzir o volume de demandas que a ele chegavam.

29 Vitor Nunes Leal, “Atualidade do Supremo Tribunal”, Revista de Direito Administrativo 78 (1964), pp. 453-459. 
Paulatinamente, as súmulas foram incorporadas pelos demais tribunais. As primeiras súmulas do STJ datam de 1990, seu segundo ano de funcionamento. Nos tribunais de justiça e nos tribunais regionais federais, a prática de publicação de súmulas de jurisprudência dominante igualmente disseminou-se nas últimas décadas, encorajada por dispositivo do próprio CPC como forma de uniformização de julgados ${ }^{30}$.

Ainda que desprovidas do efeito vinculante, as súmulas persuasivas foram progressivamente dotadas de mais autoridade conforme se modificava a legislação processual brasileira. Dentre essas modificações, destacam-se: (i) a possibilidade de julgamento monocrático pelo relator do recurso interposto ao STF ou ao STJ quando a decisão questionada estiver em confronto com os precedentes judiciais ou (ii) a sua inadmissão caso esteja em desconformidade com jurisprudência dominante ou súmula destes tribunais; (iii) a dispensa de reexame de ofício quando a decisão prolatada contra a Fazenda Pública estiver em conformidade com jurisprudência do plenário do STF ou súmula de tribunal superior; (iv) inadmissibilidade do recurso especial quando em confronto com súmula ou jurisprudência dominante do $\mathrm{STJ}^{31}$.

Mesmo após a criação da súmula vinculante, novas alterações processuais foram promovidas com vistas à racionalização do trabalho por intermédio das súmulas persuasivas, com (vi) a possibilidade de negar

\footnotetext{
${ }^{30} \mathrm{O}$ caput do art. 479 do CPC dispõe: O julgamento, tomado pelo voto da maioria absoluta dos membros que integram o tribunal, será objeto de súmula e constituirá precedente na uniformização da jurisprudência.

${ }^{31}$ Alterações promovidas respectivamente pelas leis 9.756 de 1998, que alterou a redação do Art. 557, caput e inseriu o $\S 1^{\circ}$-A do CPC; 10.352 de 2001, que modificou a redação do $§ 30$ do art. 475; 9.756 de 1998, que modificou a redação do $\S 3^{\circ}$ do art. 544
} 
seguimento a apelação quando a sentença estiver de acordo com súmula do STF ou STJ; (vii) admitir recurso extraordinário do STF quando a decisão impugnada contraria súmula ou jurisprudência dominante do STF, atendendo desde logo ao requisito da repercussão geral. ${ }^{32}$

A figura da súmula vinculante, contudo, foi dotada de ainda maior poder de determinação sobre as instâncias inferiores do que as súmulas persuasivas, não somente em razão de seu efeito vinculante, o que garante desdobramentos processuais diversos daqueles das demais súmulas, mas também por ter como destinatários, para além dos demais órgãos do Poder Judiciário, a administração pública, direta e indireta, em todas as esferas federativas. Após a sua regulamentação pela Lei 11.417, de 2006, possibilitou-se, em sede de reclamação ao STF, a responsabilização cível, administrativa e penal do agente responsável pelo descumprimento da súmula vinculante, além da substituição do ato administrativo ou decisão judicial em desconformidade com o enunciado da Corte $^{33}$.

Justamente por conta dos efeitos ampliados, a adoção da súmula vinculante revelou-se bastante polêmica na literatura jurídica. De um lado, aventou-se que as súmulas implicariam (i) violação ao princípio separação dos

\footnotetext{
${ }^{32}$ Incluídas pelas leis 11.276 de 2006 , que modificou a redação do art. $518, \S 1^{\circ}$ do CPC, 11.418 de 2006, que incluiu o art. 543-A.

33 A sanção foi inserida na Lei 9.494 pela lei 11.471 , que regulamentou o procedimento de edição, revisão e cancelamento de súmulas vinculantes: Art. 64-B. Acolhida pelo Supremo Tribunal Federal a reclamação fundada em violação de enunciado da súmula vinculante, darse-á ciência à autoridade prolatora e ao órgão competente para o julgamento do recurso, que deverão adequar as futuras decisões administrativas em casos semelhantes, sob pena de responsabilização pessoal nas esferas cível, administrativa e penal.
} 
poderes; (ii) ao pacto federativo e (iii) a supressão do livre convencimento do juiz; ${ }^{34}$ (iv) o engessamento da jurisprudência; (v) demasiada concentração de poder nos tribunais superiores; (vi) prejuízo à garantia do duplo grau de jurisdição e (vii) do princípio constitucional do direito de ação. De outro, as súmulas propiciariam (i) significativa diminuição de demandas; (ii) aumento da eficiência da administração judiciária, com a maximização do resultado e a minimização do custo; (iii) aumento da segurança jurídica, favorecendo a previsibilidade e a uniformidade do direito; (iv) redução das dilações indevidas, garantindo razoável duração do processo; (v) e, ainda, a promoção de isonomia entre jurisdicionados e (ii) o incremento da coerência normativa do ordenamento e dos discursos jurisdicionais. ${ }^{35}$

Deve-se ter em conta, entretanto, que, apesar dos debates efusivos, a súmula tão somente otimizou algumas práticas já existentes do tribunal, ao

\footnotetext{
${ }^{34}$ Nesse sentido, Julia Raquel Q. Dinamarco, Súmula Vinculante, tese de doutorado, São Paulo: Universidade de São Paulo, 2001; Evandro Lins e Silva, 'A questão do efeito vinculante'. Revista da Ordem dos Advogados do Brasil, v. 25, n. 61, p. 53 - 58, jul./dez. 1995; Jose Roberto Freire Pimenta, 'Súmulas com efeito vinculante: uma abordagem crítica', Revista TRT-3 ${ }^{a}$ Região. Belo Horizonte, 25(54): 245-248, jan.94/jun.95, p. 247-248; Sérgio Sérvulo da Cunha, O efeito vinculante e os poderes do juiz, São Paulo: Editora Saraiva, 1999; Lênio Luz Streck, Súmulas no direito brasileiro: eficácia, poder e função, Porto Alegre: Livraria do Advogado, 1995; Carmen Lúcia Antunes Rocha, Sobre a Súmula Vinculante, disponível em: http://www.teiajuridica.com/sul11vinc.html.

${ }^{35}$ Cf. Samuel Brasil Jr. Precedentes vinculantes e jurisprudência dominante na solução das controvérsias, Tese de doutorado, São Paulo: Universidade de São Paulo, 2010. p. 163 e ss. Nesse sentido, ver também Hurley, 'Coherence, Hypothetical Cases, and Precedent', Oxford Journal of Legal Studies, v.10, p. 221-251, 1990, que fala em razões fortes e fracas para que os precedentes sejam seguidos, sendo a coerência do ordenamento a razão forte, e a justiça formal, razão fraca.
} 
criar um filtro mais efetivo do que as súmulas de jurisprudência predominante. Ademais, viabilizou uma saída para a ausência de vinculação das decisões tomadas pelo tribunal em sede de controle de constitucionalidade difuso, tarefa que emprega a quase totalidade dos esforços do tribunal como veremos adiante.

Em verdade, dada a similaridade dos efeitos das súmulas vinculantes em relação às decisões em sede de controle abstrato de constitucionalidade, mesmo a legitimidade ativa para propositura de novas súmulas, de revisão ou cancelamento das existentes é idêntica a do rol do art. 102 referente às ADIs. Diversamente das decisões em controle concentrado, contudo, exige-se como requisito para criação da súmula a existência de reiteradas decisões sobre o assunto. Dado que possivelmente extraídas de decisões de controle concreto de constitucionalidade, o constituinte entendeu a necessidade de reiteração do posicionamento da corte.

Considerada, entretanto, a nova sistemática adotada da repercussão geral, justamente focada na redução de julgamentos sobre mesmo assunto, a necessidade de reiteradas decisões não parece muito coerente com as reformas empreendidas pela EC n. 45 de 2004. Pela própria dinâmica institucional de criação das súmulas, que deve ocorrer no plenário do STF, não faria sentido exigir a reiteração do posicionamento do tribunal em casos diversos, dado que já necessário o posicionamento do tribunal como um todo. Nesse sentido, Marcos Paulo Veríssimo afirma:

Ao invés de impedir o julgamento repetido de questões idênticas pelo STF, a súmula depende, justamente, da existência desses julgamentos idênticos e repetitivos, para que possa ser editada. Isso porque, nos termos do artigo 103-A da Constituição Federal, sua edição somente pode ocorrer "após reiteradas decisões sobre matéria constitucional". Em um tribunal comum de apelações, tal exigência até poderia fazer algum sentido, já que um tribunal desse tipo é composto de uma 
infinidade de magistrados, reunidos em órgãos colegiados distintos, que podem até mesmo ter interpretações distintas sobre uma mesma questão legal (esse é o modelo de cortes supremas na Europa, que encontraria alguma semelhança, no Brasil, com o arranjo institucional próprio ao STJ, como seus 33 Ministros divididos em 6 Turmas, 3 Sessões, uma Corte Especial e um Tribunal Pleno). Mas no STF, em princípio, as declarações de inconstitucionalidade (ressalvada a competência das Turmas, como visto supra), deveriam em princípio ser remetidas, prioritariamente, ao próprio Plenário. Exigir julgamentos repetitivos para que o entendimento do tribunal possa tornar-se vinculante passa a fazer pouco sentido nesse contexto, ainda mais quando se tem em conta que o regime de vinculação no controle concentrado é completamente outro e não depende de qualquer repetição.

Além do critério formal de decisões reiteradas sobre o conteúdo que versa a súmula, o constituinte também estipulou restrições temáticas para as súmulas. Assim, as súmulas devem tratar de questão constitucional, a envolver a "validade, a interpretação e a eficácia de normas determinadas". Estabeleceu ainda que a aplicação das normas objeto de súmula deveriam despertar controvérsia dentro do judiciário ou deste com a administração pública, a ponto de engendrar "insegurança jurídica e multiplicação de processos".

Em comparação com as predecessoras súmulas de jurisprudência predominante, houve menor espaço para disciplina regimental, de vez que os requisitos formais e materiais para criação das súmulas persuasivas eram tratados essencialmente nos regimentos internos. Apenas quando se tratasse de incidente de uniformização de jurisprudência aplicar-se-ia também o Código de Processo Civil, em seus artigos 476 e seguintes, sendo possível que o procedimento tivesse início por iniciativa de juiz ou de qualquer das partes quando houver divergência na interpretação do Direito. Tratando-se, contudo, 
de uma questão já pacificada na jurisprudência, mas que o Tribunal entendesse necessário edição de súmula para evitar a proliferação de demandas idênticas sobre o tema, o procedimento aplicável era exclusivamente o do regimento interno $^{36}$.

A comparação faz-se importante, pois se percebeu na prática do STF que o procedimento para edição de súmulas vinculantes não difere do que era feito na criação de súmulas persuasivas. Maria Olivia Junqueira demonstrou, empiricamente, que, na formulação das súmulas vinculantes, não há uma preocupação sistemático-conceitual em atender os pressupostos formais e materiais de edição das súmulas, muitas vezes não havendo qualquer esforço argumentativo por parte dos Ministros nesse sentido. ${ }^{37}$ Ademais, com relação à exigência constitucional de reiteradas decisões sobre a matéria, pode-se notar que o STF não se prendeu a esse critério. A súmula vinculante n. 11, sobre o uso de algemas, tornou-se célebre nesse sentido, uma vez que, além das poucas decisões mencionadas, nenhuma tratava diretamente do tema sumulado.

Desde a criação das súmulas vinculantes, o STF nunca mais editou nenhuma súmula comum, tendo inclusive, em uma oportunidade, transformado

\footnotetext{
${ }^{36}$ No Regimento do Superior Tribunal de Justiça o procedimento é regulamentado nos artigos 122 e seguintes, e no Regimento do Supremo Tribunal Federal, nos artigos 102 e 103.
}

37 Cf. Maria Olivia Pessoni Junqueira, A construção da súmula vinculante pelo STF: observação dos dezesseis primeiros enunciados de súmula vinculante editados, Monografia de conclusão da Escola de Formação, 2009 (SBDP). Disponível em: http://www.sbdp.org.br/arquivos/monografia/149_Monografia\%20Maria\%20Olivia.pdf.

Acessado em 22.10.2010. 
um de seus antigos enunciados em uma súmula vinculante ${ }^{38}$, de modo que apenas passou a rotular seus enunciados com o título de vinculantes.

Percebe-se, assim, que o procedimento anterior, disciplinado pelo regimento interno, cristalizou-se na prática do tribunal, de modo que a criação constitucional da súmula vinculante engendrou tão somente a atribuição de maior autoridade aos enunciados sumulares, de vez que a procedimento em si manteve-se intocado. Nesse sentido, Adriana Vojvodic argumenta que o trabalho de criação da súmula seria praticamente o mesmo feito para a consolidação da jurisprudência: "a diferença é que na jurisprudência consolidada não há como usá-la como fundamentação sem uma quantidade considerável de decisões. No caso da súmula vinculante, apesar da exigência constitucional de reiteradas decisões sobre a matéria, o STF cria enunciados a partir de um número menor de decisões". 39

Uma possibilidade, ausente na sistemática anterior, foi a criação de súmulas a partir do julgamento com repercussão geral, conforme previsto no

\footnotetext{
${ }^{38}$ A Súmula $n^{\circ} 648$ foi transformada na Súmula vinculante $n^{\circ} 7$ na sessão plenária de 11 de junho de 2008. Nenhuma razão foi mencionada pelos Ministros quanto a inefetividade da antiga súmula e a necessidade de criação de uma súmula vinculante endereçando o mesmo problema jurídico.

39 Adriana de Moraes Vojvodic, Precedentes e argumentação no Supremo Tribunal Federal: entre a vinculação ao passado e a sinalização para o futuro, São Paulo: Faculdade de Direito da Universidade de São Paulo, Tese de doutorado, 2012, p. 198.
} 
art. 354-E do RISTF ${ }^{40}$, situação em que, apesar de o Tribunal julgar poucos casos, é implícita a multiplicação de processos sobre o assunto. Conjugando os dois instrumentos, evita-se não apenas o julgamento de casos iguais até o momento do julgamento de mérito do caso representativo do tema que oferece repercussão geral, mas também a reiteração desse julgamento posteriormente, pois a ausência de vinculação das decisões de repercussão geral é suprida pela súmula.

Ainda que alguns ministros tenham demonstrado preocupação pela conjugação dos dois institutos ${ }^{41}$, a prática acabou prevalecendo, como afirmou o Ministro Enrique Lewandowski nos debates prévios à aprovação da súmula vinculante n. 12 :

Senhor Presidente, eu me permitiria ponderar apenas o seguinte: reconhecidamente o Supremo Tribunal Federal adotou uma praxe salutar e logo após votada a repercussão geral nós elaboramos uma súmula vinculante. Isso tem desatravancado os nossos trabalhos, tem esclarecido os jurisdicionados.

\footnotetext{
${ }^{40}$ Dispõe o mencionado artigo que "a proposta de edição, revisão ou cancelamento de súmula vinculante poderá versar sobre questão com repercussão geral reconhecida, caso em que poderá ser apresentada por qualquer Ministro logo após o julgamento de mérito do processo, para deliberação imediata do Tribunal Pleno na mesma sessão”.

${ }^{41}$ Nesse sentido, afirma o Ministro Eros Grau, na $20^{\mathrm{a}}$ sessão do plenário, realizada em 13 de agosto de 2008: hoje fico muito preocupado com o fato de da repercussão geral chegarmos diretamente à súmula. Porque há casos e casos. E hoje julgamos uma porção de recursos extraordinários, entre os quais seguramente há casos inteiramente distintos um do outro.
} 
Por fim, com relação aos desdobramentos processuais, o descumprimento de súmula vinculante ou a sua aplicação indevida enseja reclamação ao STF, que, provida, assegurará a anulação do ato administrativo ou cassação da decisão judicial. Disciplinada no regimento interno do STF (artigos 156 e seguintes), o tribunal buscou expressamente afirmar que a finalidade da ação seria preservar a autoridade das decisões da corte - perante não só os demais tribunais, mas também autoridades administrativas, de acordo com o tipo de ato impugnado. Como era de se esperar, desde 2004, houve um significativo aumento do número de reclamações perante o STF.

\section{5. Resultados quantitativos observados em relação à introdução das mudanças normativas}

De um modo geral todas as modificações de direito positivo que promoveram a vinculação de decisões do STF analisadas convergem no sentido de racionalização do trabalho do $\mathrm{STF}$, e, em alguma medida, do Judiciário como um todo quando realiza o controle difuso de constitucionalidade. Passemos então a análise de dados quantitativos relacionados a cada uma dessas mudanças.

Quanto à vinculação das decisões em sede de controle concentrado de constitucionalidade, a despeito de sua elevada importância para estancar as possibilidades de julgamentos díspares em controle difuso nas centenas de milhares de juízos, cumpre notar que as ações de controle concentrado correspondem a uma parcela ínfima das atividades do STF. Conquanto seja atribuição precípua de uma corte constitucional, no caso do STF o controle de constitucionalidade concentrado representa apenas $0,33 \%$ das decisões 
proferidas pela corte - ou cerca 201,42 ações por ano, conforme se pode observar no gráfico abaixo.

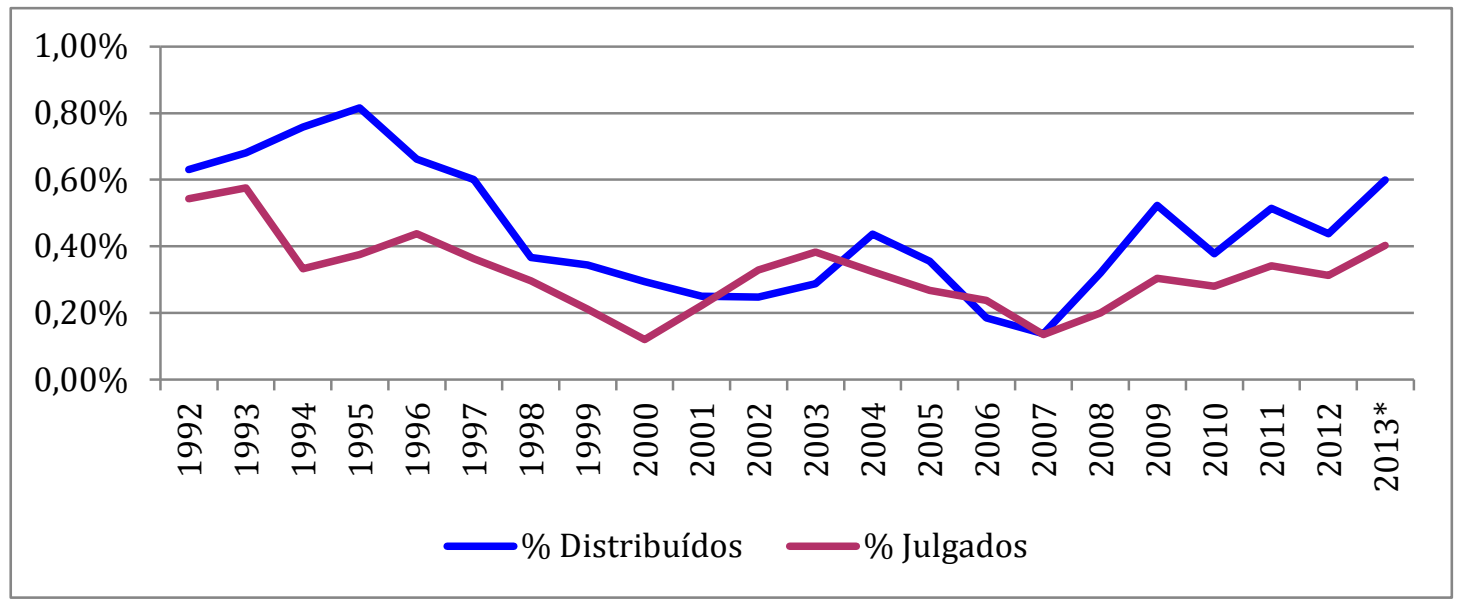

A grande maioria dos casos julgados pelo STF diz respeito ao controle concreto de constitucionalidade, sobretudo sob as formas processuais eleitas para aplicação do instituto da repercussão geral, isto é, recursos extraordinários, agravos de instrumento e recursos com agravo - ainda que essa forma de controle possa ser exercida em uma ampla gama de ações julgadas pelo tribunal, como habeas corpus, ações originárias ou mandados de injunção.

Diversamente do controle concreto, o acesso facilitado à Corte no controle difuso assegurou que a ocupação do tribunal pendesse, intensamente, para essa atividade, que chegou a representar mais de 97\% das decisões da Corte nos anos de 2000 a 2003. Considerando o caráter bastante analítico da carta de 1988, a tarefa de suscitar questões constitucionais diante de casos concretos não seria das mais complexas, o que viabilizou essa quantidade monumental de casos, tanto em termos absolutos quanto em termos relativos, nem sempre versando sobre uma questão de efetiva relevância para a "guarda da Constituição", atribuição do STF. 


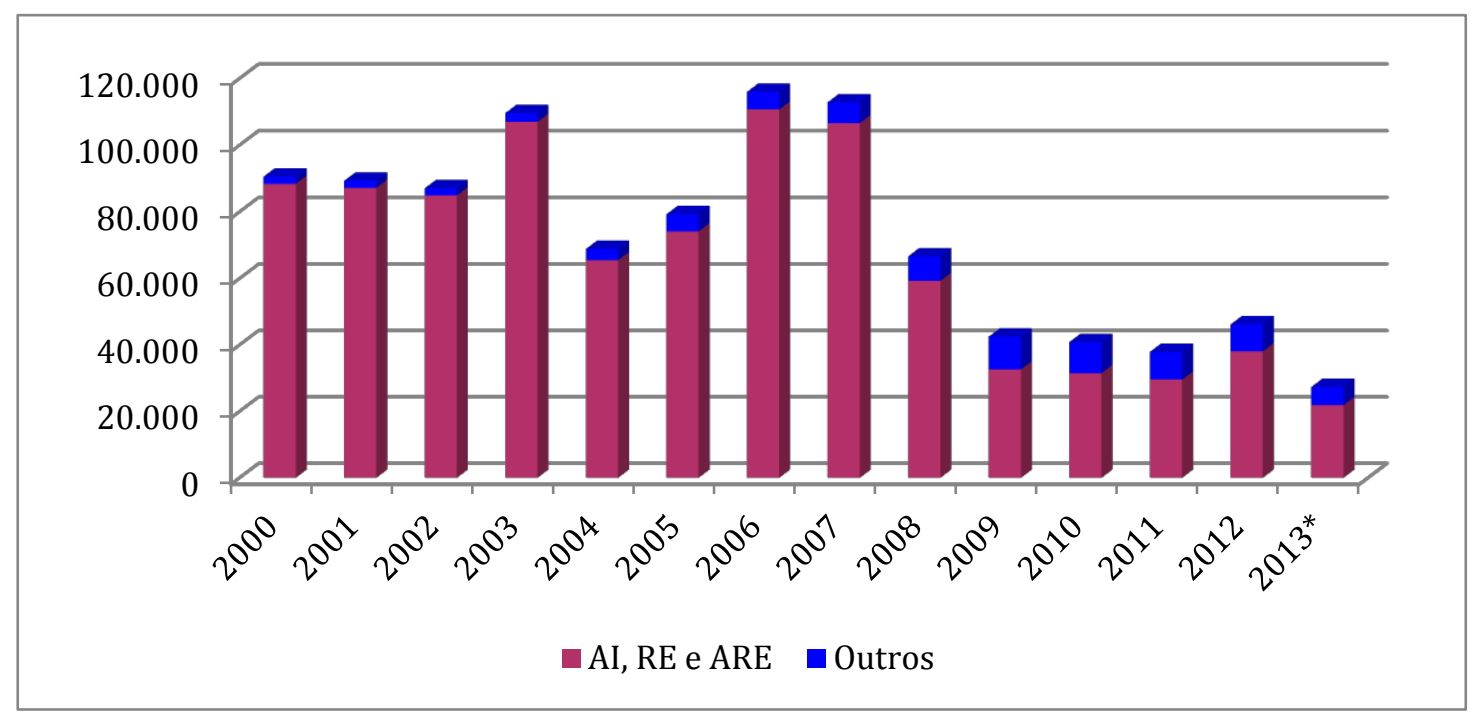

Conforme se depreende da análise do gráfico, após a introdução e regulamentação da repercussão geral e da súmula vinculante, essa porcentagem decaiu intensamente, passando a representar cerca de $76 \%$ dos processos julgados nos anos de 2009 a 2011. A despeito da significativa redução numérica, três quartos das atividades do tribunal ainda se concentram nessas três classes processuais. Desse modo, conquanto a repercussão geral tenha fortalecido os demais filtros de admissibilidade, não há como se falar que, diante de 38 mil processos ao ano ${ }^{42}$, apenas casos de extrema relevância econômica, social, política ou jurídica estejam chegando à Corte.

42 Referente ao ano de 2012, conforme o sítio do STF. Disponível em: http://www.stf.jus.br/portal/cms/verTexto.asp?servico=estatistica\&pagina=pesquisaClasseAno sAnteriores. 
Outro ponto importante a ser ressaltado é ausência de vinculação para casos futuros que não aqueles sobrestados enquanto pendente a controvérsia. Ainda que a sistemática da repercussão implique a apreciação pelo STF de apenas alguns casos eleitos representativos, de modo que aos demais deve ser aplicada, pelos tribunais de origem, a solução formulada pelo STF, posteriormente os mesmos casos poderão voltar à pauta do tribunal. A ausência de vinculação do STF aos próprios precedentes explica, em alguma medida, porque a queda no número de processos é significativa, mas nunca tenderá ao mínimo referente a novos casos nunca apreciados pelo Tribunal, como ocorre, em regra, em cortes de tradição jurídica de common law. ${ }^{43}$

Uma possibilidade de assegurar a não submissão de casos idênticos em período posterior seria a suspensão de execução da lei declarada inconstitucional em controle concreto pelo Senado Federal, de acordo com o que preceitua o art. 52, $\mathrm{X}$, dispositivo pouco empregado na prática ${ }^{44}$. Ainda que o tribunal tenha tentado dar nova interpretação ao preceito constitucional,

\footnotetext{
43 A Suprema Corte dos Estados Unidos e a do Reino Unido, por exemplo, julgam menos de 100 casos ao ano, de acordo com dados disponíveis em seus sítios oficiais. (www.supremecourt.gov/about/justicecaseload.aspx e www.supremecourt.gov.uk/decidedcases/index.html).
}

${ }^{44}$ Pesquisa empírica realizada por Beatriz Alencar Dalessio indica a existência de apenas 448 ofícios referentes à suspensão de execução de lei pelo Senado no intervalo temporal de 1953 a 2011, número assaz pequeno tendo em vista os mais de 100.000 REs, AIs e REs com AI julgados anualmente pelo STF. Ademais, para além do fato de apenas 74,2\% dos casos terem sido endereçados por resolução suspensiva senatorial, o lapso temporal chega a 10 anos. Para mais, ver: Senado federal e o STF: um estudo sobre a suspensão de lei declarada inconstitucional, disponível em: http://www.sbdp.org.br/arquivos/monografia/205 Beatriz\%20A.\%20Dalessio\%20\%20Monografia $\% 20(2) \% 20(1) . p d f$. 
como discutiremos no próximo capítulo, a solução deu-se pela conjugação dos institutos da repercussão geral e da súmula vinculante. Desse modo, pode-se garantir efeito vinculante ao posicionamento do tribunal firmado em sede de controle difuso, tornando desnecessário conferir nova interpretação à competência do Senado de suspender a execução de lei inconstitucional. Esse ponto será analisado em maior profundidade no próximo capítulo.

Com relação aos resultados relativos à introdução da súmula vinculante, houve aumento contínuo do número de reclamações perante o STF, o que pode ser relacionado com casos em que se questiona a aplicação das súmulas por instâncias inferiores.

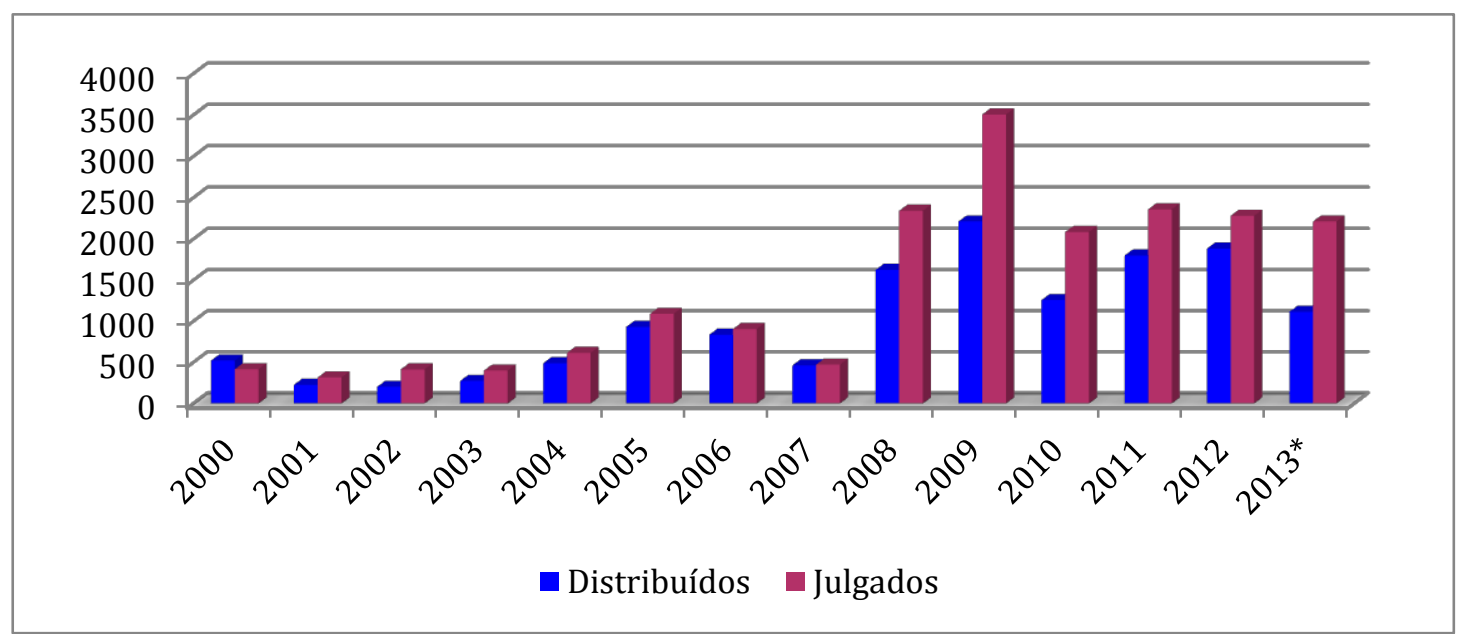

Para além da discussão sobre a mutação constitucional do art. 52, X da $\mathrm{CF}$, foi também em sede de reclamação que se teve as discussões acerca do alcance das disposições vinculantes das decisões, tese que ficou conhecida como "transcendência dos motivos determinantes", segundo a qual seria vinculante não só o dispositivo das decisões, mas também os motivos para sua 
adoção ${ }^{45}$, o que garantiria vinculação da integralidade dos precedentes do STF. Ambos os pontos serão abordados de forma detida nos próximos dois capítulos.

Por fim, no que tange a redução da sobrecarga de trabalho do restante do Judiciário, nota-se redução sensível no índice de congestionamento do Judiciário, elaborado pelo Conselho Nacional de Justiça (CNJ) e calculado anualmente de acordo com a fórmula abaixo. Em 2003, as taxas de congestionamento da justiça federal eram de $81,37 \%$ e $76,23 \%$ no $1^{\circ}$ e $2^{\circ}$ grau respectivamente $^{46}$. Em 2012, a taxa global da justiça federal foi de $65 \%{ }^{47}$.

\section{R: 1 - Sent $/ \mathbf{C N}+\mathbf{C} \mathbf{p j}+\mathbf{C e x}$}

Onde:

Sent: sentenças, acórdãos, decisões e despachos que põem fim ao processo;

${ }^{45}$ Ver, nesse sentido, Rcl 3294 AgR, Rcl 9778 AgR, Rcl 3385 AgR e Rcl 6319 AgR, entre outras.

46 Justiça em números 2003, Variáveis e indicadores do Poder Judiciário, Conselho Nacional de Justiça - Brasília: CNJ, p. 205 e 206, Disponível em: http://www.cnj.jus.br/images/pesquisas-judiciarias/Publicacoes/relatorio_jn2013.pdf

47 Justiça em números 2013: ano-base 2012/ Conselho Nacional de Justiça - Brasília: CNJ, p. 184.

Disponível

em:

http://www.cnj.jus.br/images/stories/docs_cnj/relatorios/justica_numeros_2003.pdf 
CN: Casos novos;

Cpj: Casos pendentes de julgamento;

Cex: processos sentenciados em execução;

De acordo com os relatórios do $\mathrm{CNJ}$, a redução tem-se dado a despeito do aumento contínuo de casos novos, em razão do aumento de produtividade dos juízos. Os filtros de admissibilidade e a aplicação direta das súmulas podem ser fatores explicativos dessa redução do congestionamento por aumento das decisões prolatadas. Ainda antes da reforma do Judiciário, a legislação processual já estava sendo gradativamente alterada para dar força normativa aos precedentes dos demais tribunais superiores, notadamente por intermédio de mecanismo de impedimento de recurso e de simplificação do julgamento de casos passíveis de subsunção às hipóteses fáticas das súmulas. Desse modo, além da redução dos recursos, a simples aplicabilidade dos entendimentos sumulares possibilitaria a redução do congestionamento do Judiciário.

De um modo geral, pode-se dizer que as medidas introduzidas apresentaram resultados auspiciosos no que tange à redução da sobrecarga de trabalho - e, ao decidir menos, vinculando instâncias inferiores, à uniformização das decisões judiciais a partir da jurisprudência do STF. A necessidade de se alçar, normativamente, as decisões judiciais a um papel de maior relevo na produção do direito é indicativa, contudo, dos fatores culturais refratários à prática de se seguir precedente e argumentar com olhar prospectivo. 


\section{Fatores institucionais relacionados à vinculação a precedentes.}

A acumulação de funções da Corte, os procedimentos decisórios, tanto no exercício do controle de constitucionalidade difuso e concentrado quanto no desempenho das competências recursais, e as dinâmicas institucionais entre a Corte e os demais poderes podem ser considerados fatores com grande potencial de influência sobre a eficácia dos mecanismos de vinculação de decisões.

Michelle Taruffo e Massimo de la Torre afirmam que fatores institucionais são determinantes na forma como precedentes serão seguidos ao menos em duas maneiras: (i) definindo quais cortes criam precedentes vinculantes, como eles são criados e o que é de fato considerado um precedente; (ii) determinando como e quais precedentes devem ser usados pelas cortes e demais atores sociais ${ }^{48}$. Restrito o presente estudo ao STF, a análise do seu desenho institucional, sobretudo no que tange ao modelo de deliberação e tomada de decisão - o "como" são proferidos precedentes vinculantes - e sua dinâmica com os demais poderes e com os órgãos inferiores do próprio judiciário - o que pode esclarecer, em alguma medida, a força desses precedentes - serão os pontos principais a serem analisados neste capítulo.

48 “Precedents in Italy", In: Interpreting Precedents, 1997. 


\section{1. O desenho institucional do STF e sua multiplicidade de funções}

Muito embora dotado de prerrogativas de uma corte constitucional, porquanto responsável pelo resguardo da Constituição Federal, o STF não é perfeitamente enquadrável em tal categoria. Ao lado de suas competências propriamente constitucionais, o STF tem também uma série de outras atribuições institucionais, que o levam, na maior parte do tempo, a exercer funções de um tribunal recursal de última instância. Ademais, a inclusão da corte na hierarquia institucional do Poder Judiciário brasileiro diferencia-o das cortes constitucionais propriamente ditas, órgãos normalmente apartados do restante do Judiciário. Mais do que uma mera consideração de topografia institucional, é este o fato determinante para a possibilidade de atribuição de funções recursais à corte, na medida em que inserida no topo da pirâmide hierárquica do Judiciário.

Esses são fatores de extrema relevância em um estudo sobre vinculação das decisões da corte, pois foi essa acumulação de competências constitucionais e recursais que implicou a excessiva carga de trabalho submetida ao STF, motivadora das modificações normativas que atribuiriam força vinculante a seus precedentes. Com efeito, a multiplicidade de tarefas do STF acrescida da ampliação do acesso à corte - seja no controle de constitucionalidade, seja nas demais categorias de ações de competência do tribunal - fez necessárias medidas de racionalização do trabalho da corte. As mudanças normativas voltadas à instituição de força vinculante às decisões do STF garantiriam, assim, a submissão das instâncias inferiores e a restrição do número de casos passíveis de serem admitidos perante o tribunal. A vinculação de decisões foi, dessa forma, uma das tentativas de se endereçar os problemas derivados do desenho institucional do STF como corte responsável não só pela 
guarda precípua da constituição, mas também pela última palavra em casos os mais variados.

As competências do STF foram delimitadas na Constituição Federal, em seu art. 102. Em 2004, a elas foi agregada a competência de criação de súmulas vinculantes, com a introdução do art. 103-A. Já nos detivemos exaustivamente na análise das mudanças introduzidas pela Constituição de 1988 e a pela Emenda Constitucional n. 45 de 2004 relacionadas à vinculação de decisões no capítulo precedente. Aqui, contudo, cumpre retomar apenas dois pontos além da acumulação de funções recursais e constitucionais de que temos falado: a conjugação do controle concentrado e difuso e a ampliação do acesso à corte em ambos os casos. No tocante ao controle de concentrado, houve a ampliação do rol de legitimados ativos para proposição de casos desde a promulgação da chamada, por essa e outras razões, constituição cidadã. No que tange ao controle difuso, a carta eliminou os critérios de relevância para admissibilidade, característica que vem a se somar as já mencionadas acerca do distanciamento do desenho institucional do STF daquele que é empregado, usualmente, em cortes constitucionais, dotadas de ampla margem de discricionariedade na admissão de casos. Tais características tem grande potencial explicativo a respeito do aumento exponencial de processos distribuídos e julgados pelo STF, que passaram de 16 mil ao ano no início da década de 1990 para mais de 110 mil em 2006, quando então se inicia decréscimo significativo e contínuo.

Para além da reintrodução dos requisitos de relevância - a repercussão geral -, o endurecimento na interpretação dos critérios processuais de admissibilidade e a introdução de outras medidas relacionadas à atribuição de força de vinculação, como a criação das súmulas vinculantes e as reformas processuais que conferiram às súmulas jurisprudenciais a qualidade de efetivos filtros recursais, houve ainda, tentativas de reinterpretação dos efeitos das decisões em controle difuso e concentrado pelo próprio tribunal no esforço de 
vincular cada vez mais as instâncias inferiores, bloqueando, assim, a chegada de novos casos à corte. Esse último ponto será abordado no próximo capítulo.

No que concerne à repercussão geral, do ponto de vista institucional, é importante notar que não há ampla capacidade de seleção de casos pelo tribunal. Muito embora a comparação com o writ of certiorari do direito anglosaxão seja válida, deve se ter em conta que abundam diferenças entre este instituto e a repercussão geral. Aquele é aplicável a todo e qualquer caso submetido à suprema corte e utilizado a exaustão, de modo que é julgada apenas uma quantidade diminuta de casos. Trata-se, assim, de instrumento para efetivo exercício da discricionariedade na seleção de casos de extrema relevância para a nação e para a ordem constitucional do país. A repercussão geral, por sua vez, restringe-se à admissibilidade de casos de controle difuso de constitucionalidade e tão somente se não atendido o critério de relevância, que, ainda que comporte um grau de discricionariedade, garante, hodiernamente, a admissão de dezenas de milhares de recursos extraordinários ao ano.

Conquanto se esteja observando redução do trabalho do STF, resultado, em grande medida, da reintrodução deste instituto como vimos no capítulo anterior, o volume de casos é ainda bastante mais elevado em comparação com cortes que seguem, em alguma medida, o stare decisis. A Suprema Corte Americana, por exemplo, julga, em plenário, menos de 100 casos ao ano, número que se tem mantido estável em que pese o acréscimo substancial de casos a ela submetidos. Ademais, a publicação de todas as decisões, opiniões concorrentes e divergentes e mandados judiciais é de cerca de 5000 páginas ${ }^{49}$.

\footnotetext{
49 De acordo com o sítio da Suprema Corte Americana: the Court's caseload has increased steadily to a current total of more than 10,000 cases on the docket per Term. The increase has been rapid in recent years. In 1960, only 2,313 cases were on the docket, and in 1945, only
} 
A comparação destes números com os do STF é assaz contrastante: em 2012, o tribunal julgou 87.784 processos, no ano anterior as estatísticas margeavam 100 mil casos. No que tange à extensão das decisões do tribunal, o número de páginas da Ação Penal 470, por si só, já é bastante ilustrativo. Tão somente em sua primeira fase de julgamento, já continha 8.405 páginas. Ainda que seja um caso deveras excepcional, não é incomum no histórico do tribunal acórdãos de centenas ou mesmo milhares de páginas. A vinculação dos juízes e cortes inferiores em relação às decisões do STF, diante do número de casos julgados e do somatório de páginas de ementas, relatórios, votos e debates, torna-se, na prática, inviável ${ }^{50}$.

1,460. Plenary review, with oral arguments by attorneys, is granted in about 100 cases per Term. Formal written opinions are delivered in 80 to 90 cases. Approximately 50 to 60 additional cases are disposed of without granting plenary review. The publication of a Term's written opinions, including concurring opinions, dissenting opinions, and orders, approaches 5,000 pages. Some opinions are revised a dozen or more times before they are announced. Disponível em: http://www.supremecourt.gov/about/justicecaseload.aspx.

\footnotetext{
${ }^{50}$ Nesse sentido, Mauro Capelletti, ao comparar a tradição de civil law e common law indica o número de casos como fator incontornável para a compreensão da ausência de autoridade dos precedentes nos sistemas jurídicos do primeiro tipo: "when the decisons of a higher court are given in thousands, most of them will remain unknown and unpublished, or only summarily published; they are doomed to be forgotten even by the court itself. The few important ones are submerged and diluted by the very many which are irrelevant and routine, and the court has no possibility to give them the necessary relief. (...) The end result, insofar as our problem is concerned, is that the precedential authority of higher court decisions in the former systems is far from being comparable to that of decisions given by higher courts in the latter". "The Doctrine of Stare Decisis and the Civil Law: A Fundamental Difference - or no Difference at All?', In: Festschrift für Konrad Zweigert zum 70. Geburstag, Tübingen, J.C.B. Mohr, 1981, p. $386 .^{50}$
} 


\section{2. Procedimentos decisórios no Supremo Tribunal Federal}

A análise do modelo deliberativo e decisório seguido pelo STF é bastante elucidativa quanto à extensão das decisões da corte e mesmo do volume de casos julgados. Ademais, dentre os fatores institucionais que influenciam potencialmente na vinculação de decisões, o procedimento decisório tem particular relevância. Isso porque é ele que garante a possibilidade de debate entre os ministros, antes ou durante o julgamento, assegurando a deliberação conjunta. Ausente ou restrito o debate, a deliberação é prejudicada, porquanto os votos passam a ser produzidos a portas fechadas de gabinetes e apenas lidos em plenário diante dos demais ministros.

No caso do STF, o procedimento decisório é matéria regulamentada no regimento interno da Corte (RISTF), ainda que parte substancial se tenha consolidado na prática do tribunal, como é o caso da produção prévia dos votos. O regimento estabelece como deve ser a distribuição dos casos, o procedimento a ser seguido na sessão de julgamento, a função do relator, os debates entre os ministros e a forma de publicação dos votos, apartes e debates.

A distribuição dos processos é, em regra, realizada mediante sorteio, automático e aleatório. Não é possível, portanto, escolha dos casos pelos ministros que os relatarão, como sói ocorrer em todos os tribunais brasileiros. Relatado, o caso é então remetido à turma ou ao plenário, de acordo com as competências regimentais de cada um. É o relator que deve solicitar dia de julgamento ou apresentar em mesa os casos que independam de pauta. Desse 
modo, o tempo processual é, em grande medida, definido pela atuação do relator da causa ${ }^{51}$.

Compete ao relator, ainda, o não conhecimento ou a denegação de seguimento de recurso inadmissível, improcedente ou contrário à jurisprudência dominante ou à súmula do Tribunal ou o provimento do recurso extraordinário quando em manifesta divergência com súmula. A jurisprudência consolidada e as súmulas agregam-se, desse modo, aos critérios de admissibilidade de recursos como filtros para limitação do número de casos submetidos às turmas e ao plenário. Com efeito, o contraste entre o número de casos processados e julgados pelo tribunal e o número de acórdãos efetivamente publicados indica a existência de filtros bastante eficazes, na medida em que somente haverá acórdão dos casos não decididos monocraticamente. Segundo Marcos Paulo Veríssimo:

Levadas em conta as disposições normativas relevantes, é possível dizer que, grosso modo, as estatísticas relativas à publicação de acórdãos, divulgadas pelo STF, podem ser lidas como indicativas do número de processos julgados, a cada ano, pelas Turmas ou pelo Plenário, o que equivale, em termos aproximados, ao número de casos julgados de forma colegiada. As estatísticas de casos julgados e acórdãos publicados ao ano dizem, portanto, que a imensa maioria dos processos resolvidos atualmente pelo STF (algo em torno de $88,20 \%$

\footnotetext{
51 O pedido de vista é outro fator de extremo impacto no tempo de transcurso de um julgamento. Cumpre notar, nesse ponto, que a prática do tribunal afasta-se, mais uma vez das previsões regimentais. Com efeito, o art. 134 do regimento, determina que, no caso de pedido de vista, o Ministro solicitante deverá reapresentar o caso, para prosseguimento da votação, até a segunda sessão ordinária subsequente. Todavia, há casos em que o pedido de vista perdura anos a fio.
} 
deles, utilizando-se o proxy da média de acórdãos publicados verificada para a década de 2000) não são, ao final das contas, levados a julgamento colegiado, quer nas Turmas, quer no Plenário. Ao contrário, são objeto de julgamento monocrático ${ }^{52}$.

Às condições de admissibilidade ressaltadas pelo autor podemos então agregar as súmulas e a consolidação jurisprudencial como filtros igualmente aptos à redução do trabalho da corte. Em todos esses casos, o relator é o agente principal na execução desse "certiorary à brasileira".

Ainda sobre o papel do Ministro Relator, cumpre notar a função de apresentação do caso aos demais ministros. Em regra, o relatório é o único contato com os detalhes do caso por parte dos ministros não imbuídos da função de relatoria. De todo modo, as funções do relator são mais de ordem procedimental e de exposição factual do que de condução das discussões entre os ministros. Não obstante a previsão do RISTF de debate oral anterior à tomada de votos, apenas em julgamentos de maior relevo ${ }^{53}$, que se desdobram em diversas sessões, há espaço de deliberação prévio à confecção final dos votos. Isso porque, na prática consolidada do tribunal, os votos são trazidos prontos pelos ministros, o que dificulta a deliberação conjunta e a mudança de posição, conquanto seja possível alteração dos votos mesmo depois de sua leitura por ressalva do próprio regimento.

O obstáculo regimental à deliberação conjunta pode ser apontado na previsão de tomada de votos individuais. Combinada à praxe de votos extensos, tem-se como natural consequência a inviabilização da deliberação

\footnotetext{
${ }^{52}$ Veríssimo, Op. Cit. p 419.

${ }^{53}$ Vide Art. 135 do RISTF.
} 
interna com vistas à produção de decisões do tribunal como instituição e não como um agregado de juízes que não conversam entre si.

Com efeito, dado o elevado número de casos julgados e a monumental quantidade de páginas dos votos e dos acórdãos, é natural que os ministros necessitem elaborar previamente seus votos com auxílio de diversos assessores. Trazidos prontos para a sessão de julgamento, sobretudo em casos de grande complexidade, os debates restam inócuos, com mínimas possibilidades de convencimento e mudança de posição.

Nesse sentido, Virgílio Afonso da Silva aponta como características determinantes do processo decisório do STF as seguintes:

(1) quase total ausência de trocas de argumentos entre os ministros: nos casos importantes os ministros levam os votos prontos para a sessão de julgamento e não estão ali para ouvir os argumentos de seus colegas de tribunal; (2) inexistência de unidade institucional e decisória: o Supremo Tribunal Federal não decide como instituição, mas como a soma dos votos individuais de seus ministros; e (3) carência de decisões claras, objetivas e que veiculem a opinião do tribunal: como reflexo da inexistência de unidade decisória, as decisões do Supremo Tribunal Federal são publicadas como uma soma, uma colagem de decisões individuais; muitas vezes é extremamente difícil, a partir dessa colagem, desvendar qual foi a real razão de decidir do tribunal em determinados casos, já que, mesmo os ministros que votaram em um mesmo sentido podem tê-lo feito por 
razões distintas ${ }^{54}$.

A reflexão sobre as características leva-nos a conclusão de uma causalidade consecutiva entre elas. A ausência de deliberação entre os ministros resulta em decisões como agregado de opiniões individuais que não dialogam entre si; inexiste, por essa razão, um posicionamento uno da corte, o que dificulta a compreensão das decisões para além do seu dispositivo final, de vez que muitas vezes não há uniformidade de razões de decidir nos votos dos ministros que formaram a maioria. O resultado é ausência de parâmetros claros sobre a interpretação constitucional do STF, o que poderia pautar a atuação dos demais poderes no exercício de suas funções normativas e mesmo da sociedade civil, quando imbuída de legitimidade ativa para provocar o tribunal. Ao fim e ao cabo, o modelo deliberativo do STF, ou a ausência de um, obstaculiza o entendimento das decisões da corte, não apenas pelas demais instituições políticas e pela sociedade, mas também pelos próprios órgãos judiciários inferiores a elas vinculados.

O obscurantismo das decisões do STF é ainda agravado quando a multiplicidade de argumentos trazidos pelos ministros fundamenta conclusões diversas e nem mesmo o próprio tribunal compreende o resultado do "placar final" de votos. A ADI 2.591, que discutiu a possibilidade de aplicação de dispositivos do Código de Defesa do Consumidor aos serviços bancários, é emblemática nesse sentido. Ao final do julgamento, não se sabia qual havia sido a decisão e muito menos as razões a ela subjacentes, o que motivou a redação de uma ementa em confronto direto com a posição prevalecente nos

\footnotetext{
54 “O STF e o controle de constitucionalidade: deliberação, diálogo e razão pública”, in Revista de Direito Administrativo 250, 2009, pag. 217.
} 
votos da maioria. A decisão final somente tornar-se-ia clara para as partes, para a sociedade e para o próprio Tribunal nos embargos de declaração.

A existência de casos como esse, em que o somatório de votos individuais fazem as vezes da deliberação e da construção de uma decisão una do tribunal como institiuição, motivou o diagnóstico das onze ilhas de Conrado Hübner Mendes ${ }^{55}$. Sustenta Mendes que:

\begin{abstract}
Argumentos "do tribunal" quase nunca existem, exceto por obra de uma metáfora. Não há, exceções à parte, razões compartilhadas pela maioria dos ministros, razões que, boas ou ruins, pudéssemos generalizar como do tribunal. Se perguntarmos por que o STF decidiu um caso numa determinada direção, não raro ficamos sem resposta. Ou melhor, ficamos com muitas respostas que nem sequer conversam entre si, expressas nos votos dos 11 ministros.
\end{abstract}

Para além da ausência de clareza nas decisões, a construção de decisões como somatório de votos também enfraquece a autoridade institucional da corte. Ao final de cada julgamento, há onze diferentes decisões, cada uma trilhando caminho argumentativo diverso e chegando em conclusões igualmente distintas pelas mesmas ou outras razões. A mensagem enviada aos demais atores institucionais resta, assim, deveras fragilizada, sobretudo quando se tem em mente a deferência dos demais órgãos judiciários.

\footnotetext{
${ }^{55}$ MENDES, Conrado Hubner. "Onze ilhas". Folha de S. Paulo, São Paulo, $1^{\circ}$ de fevereiro de 2010, Tendências/Debates, disponível em: http://www1.folha.uol.com.br/fsp/opiniao/fz0102201008.htm.
} 
Ademais, o modelo deliberativo, ou de ausência de deliberação, do STF desvirtua a própria essência do julgamento colegiado. Conquanto composto por onze ministros, o tribunal deve ser instituição coesa, de modo que suas decisões possam servir de guia para demais órgãos judiciários ou mesmo para o próprio tribunal no futuro. A existência de julgamentos em plenário é indicativa nesse sentido, nos quais deve ter lugar o diálogo voltado ao contraste de argumentos, ao convencimento e à persuasão e à construção de uma posição final una do tribunal, que leve em conta todos os argumentos suscitados pelas partes e ponderados por seus membros e que reflita as conclusões finais da maioria.

Com julgamentos colegiados que se realizam pela soma de uma pluralidade de votos - individualmente proferidos e publicados -, não há de haver uma decisão, mas tantas quantos forem os votos publicados, cada qual com razões de decidir diversas, ainda que haja convergência na decisão final. $O$ resultado final torna-se, por vezes, carente de fundamentação jurídica, ainda que haja uma multiplicidade de argumentos pró e contra elencados e sopesados nos votos dos ministros. Desse modo, a vinculação de órgãos judiciários inferiores às decisões do tribunal pode dar-se apenas em relação ao dispositivo final dos acórdãos, de vez que nem sempre há uma fundamentação única aceita pela maioria vencedora.

Dada a dificuldade de vinculação de decisões nessas circunstâncias, as súmulas foram uma maneira bastante engenhosa de contornar a ausência de unidade institucional e objetividade decisória. Mediante a formulação de um enunciado, acordado por todos os ministros, tornar-se-ia desnecessária a atividade de interpretação dos precedentes e identificação de suas razões de decidir ou o que mais fosse considerado vinculante. No controle concentrado, a solução já havia sido a atribuição de força vinculante apenas ao dispositivo final que declara a constitucionalidade ou inconstitucionalidade de determinado preceito normativo, conquanto o tribunal tenha aventado a tese da vinculação 
dos motivos determinantes e a discutido intensamente nos últimos anos ${ }^{56}$. Já, no controle difuso, a existência de particularidades factuais, inerentes à discussão da constitucionalidade de um dispositivo normativo em face de um caso concreto, tornam a atribuição de efeito vinculante às decisões do STF deveras mais complexa. Com efeito, o efeito vinculante da decisão no tocante à questão constitucional discutida foi assegurado pelo constituinte apenas depois de manifestação do Senado. Após a tentativa do STF de inaugurar uma nova dinâmica institucional mediante reinterpretação da Constituição, em seu dispositivo que atribuía tal competência ao Senado, a criação da súmula tornou potencialmente dispensável a aquiescência senatorial. Vejamos o caminho então percorrido.

\section{3. A vinculação em controle difuso: a tese da mutação constitucional}

A complexidade da dinâmica institucional necessária para atribuição de efeito vinculante às decisões do STF em controle difuso, que dependiam da comunicação do Senado via ofício e a posterior publicação, por parte do Senado, da suspensão da executoriedade da lei declarada inconstitucional pelo Supremo, tornou pouco usual o emprego do art. 52, X da CF. Com a imperativa

\footnotetext{
${ }^{56}$ Ver, por exemplo, Reclamações 2.363, Rel. Min. Gilmar Mendes, Plenário; 4.692-MC, Rel. Min. Cezar Peluso; 4.387-MC, Rel. Min. Celso de Mello; 4.416-MC, Min. Celso de Mello, decisão monocrática; 1.987, Rel. Min. Maurício Corrêa; 2.291-MC, Rel. Min. Gilmar Mendes, decisão monocrática; e ADIs 541/PI, 171/MG, 301/AC, 304/MA, 464/GO, 465/GO, 549/DF, 774/RS.
} 
necessidade de reduzir a carga de trabalho do tribunal, concentrada, em ampla medida, no controle difuso de constitucionalidade, o Ministro Gilmar Mendes, na Reclamação 4335-5/AC, desenvolveu a tese de mutação constitucional, segundo a qual a função desempenhada pelo Senado seria apenas de conferir publicidade às decisões tomadas pelo STF, de sorte que, mesmo em controle difuso, haveria vinculação de decisão que declara a inconstitucionalidade de um ato normativo.

O julgamento arrasta-se desde o início de 2007. Nesse ínterim, outra solução para o mesmo problema foi encontrada na prática, com a conjugação da repercussão geral com a súmula vinculante. Ao sumular o conteúdo das decisões de casos eleitos como representativos da repercussão geral, o STF efetivamente blinda-se da chegada de novos processos sobre o mesmo tema. Desse modo, questão semelhante somente pode retornar a pauta de julgamento do tribunal em sede de reclamação, caso desrespeitado o enunciado sumular.

Interessante notar nesse sentido que a própria reclamação 4335-5/AC teria perdido objeto por conta dessa nova dinâmica institucional do STF, como indicou o relator Ministro Gilmar Mendes por ocasião da última sessão de julgamento, em que proferiu voto Ricardo Lewandowski. Isso porque, com a edição da súmula vinculante n. 26 , que reafirma a inconstitucionalidade do artigo $2^{\circ}$, da Lei 8.072, em dezembro de 2009, o juiz reclamado restou obrigado a seguir o que havia julgado o STF no Habeas Corpus 82.959, um dos precedentes que deram origem à súmula ${ }^{57}$.

Se a dinâmica possibilitada pela repercussão geral acrescida da súmula fez a tese da mutação constitucional perder parcela da importância, na medida

\footnotetext{
${ }^{57}$ Vide: http://www.stf.jus.br/portal/cms/verNoticiaDetalhe.asp?idConteudo=238713.
} 
em que contornada a dificuldade previamente existente, a perda de objeto da própria ação em que se discutia a atribuição de efeito vinculante às decisões do STF em controle difuso e a reconfiguração da competência do Senado é indicativa da efetividade prática da nova solução.

Cumpre, por fim, notar que a nova solução é ainda mais abrangente que a possibilidade de conjugação de esforços do Supremo e do Senado. Conforme dispõe o preceito constitucional, a competência do Senado consiste apenas na suspensão de execução de lei inconstitucional, inoperante, portanto, nos casos em que o STF julgasse constitucional determinado ato normativo. Desse modo, mesmo que agilizada a dinâmica institucional entre o Senado e o Supremo, uma grande quantidade de casos de controle concreto não poderia ser atribuída dos efeitos decorrentes da manifestação senatorial.

\section{4. A interação externa: a publicidade das sessões de julgamento do STF}

Um último aspecto institucional a ser abordado é a interação do Supremo Tribunal Federal com a sociedade civil. Ainda que já se tenha sido discutido brevemente o tema quando abordado o modelo decisório adotado pelo STF e a ausência de sinais claros enviados pelo tribunal à sociedade civil, não foi examinada a publicidade das decisões e das atividades do Supremo como condição para a interação com a sociedade civil. Trata-se de fator de relevo, na medida em que a vinculação às decisões do STF depende da difusão de seu conteúdo e de seu conhecimento - ao menos pelos demais órgãos do Judiciário. 
No caso do STF, a publicidade, aparentemente, não é um problema, na medida em que todos os acórdãos são publicados e disponibilizados na internet. A publicação das decisões do STF é também matéria regimental. O art. 961 do RISTF estabelece que todo e qualquer julgamento deve ter a transcrição do áudio, incluindo os votos, o relatório e os debates. Há, ainda, desde 2002, a transmissão televisiva das sessões de julgamento por intermédio da TV Justiça $^{58}$. Criada pelo governo federal como um canal básico e gratuito, reservado ao Supremo, para a divulgação dos atos do Judiciário e de serviços essenciais à Justiça, a TV Justiça passou a transmitir ao vivo as sessões de julgamento do tribunal, algo inédito à época.

A publicidade irrestrita a que se submete o tribunal desde então criou a sensação de ser possível controle total sobre as atividades da corte por parte da sociedade civil. Ocorre que, diante dos fatores abordados nos tópicos anteriores, tais como a quantidade de decisões e sua usual extensão, é difícil imaginar que seja possível tal controle sobre as atividades do tribunal. A publicidade não assegura a cognoscibilidade das decisões tribunal. Pelo contrário, ao inibir a deliberação e a construção colegiada das decisões, é um fator de estímulo à produção prévia de votos e à intransigência individual no debate televisionado, resultando em decisões menos objetivas, mais extensas e sem unidade de fundamentação.

Virgilio Afonso da Silva e Conrado Hubner Mendes argumentam, nesse sentido, que há uma importante diferença entre publicidade e a transparência do Tribunal:

Transmissões ao vivo e acórdãos disponíveis na internet, entre outras

\footnotetext{
${ }^{58}$ Ver art. 23, I, 'h' da lei 8.977 de 1995.
} 
medidas, criaram um mito de transparência que precisa ser desconstruído. Ao contrário do que muitos tentam fazer crer, publicidade e transparência não têm nenhuma relação direta $\mathrm{e}$ necessária com a quantidade de julgamentos transmitidos pela TV. Um tribunal constitucional transparente é aquele que decide com base em argumentos transparentes, que não disfarça dilemas morais por trás de retórica jurídica hermética, que não se faz surdo para os argumentos apresentados pela sociedade. Em suma, é aquele que expõe abertamente os fundamentos de suas decisões para que sejam escrutinados no debate público. Contudo, se nos perguntarmos o que o STF pensa sobre várias das questões constitucionais relevantes, dificilmente alguém saberá responder com precisão, a despeito da quantidade de decisões disponíveis na internet e de julgamentos transmitidos pela televisão ${ }^{59}$.

O "mito da transparência" a que se referem os autores interessa ao presente estudo, pois influi diretamente na deliberação colegiada e, desse modo, na construção e justificação decisória, temas que serão abordados no próximo e último capítulo. De todo modo, a publicidade das atividades do STF é, notadamente, um fator que influencia os procedimentos decisórios e, por essa razão, pode ser relacionado às dificuldades de cognoscibilidade das decisões, questões institucionais com influência direta na efetividade dos mecanismos vinculação das decisões da corte. Ao inibir o debate franco e a deliberação conjunta, a interação com o restante da sociedade, mediante a transmissão televisionada e a publicação virtual das decisões, é assim fator que

\footnotetext{
59 “Entre a transparência e o populismo judicial”, In: Jornal Folha de São Paulo, São Paulo, 11 de maio de 2009, Tendências/debates. Disponível em: http://www1.folha.uol.com.br/fsp/opiniao/fz1105200908.htm.
} 
interfere na interação interna entre os ministros, estimulando a produção prévia de votos, ao invés da abertura ao diálogo e ao argumento formulado pelos demais membros da corte. 


\section{Cultura de precedentes e vinculação}

Nos capítulos anteriores, analisei as modificações normativas que instituíram mecanismos de vinculação judicial às decisões do STF e algumas condicionantes institucionais de relevo. Conquanto os resultados apresentados desde a sua implementação pudessem ser interpretados mediante análise dos textos legais e do desenho institucional adotados e comparação com análogos de locais que, tradicionalmente, vinculam juízes e cortes inferiores às decisões da corte constitucional, há que se ter em conta que importantes condicionantes de ordem cultural podem interferir na operacionalização de mecanismos normativos de vinculação de decisões introduzidos nas últimas décadas.

A efetividade de um texto legal ou de um arranjo institucional é condicionada pela forma como se dá sua aplicação pelos operadores do direito, pelas práticas e tradições consolidadas e pelas demandas de juridificação da sociedade. Dessa forma, um texto legal ou um arranjo institucional considerado insatisfatório diante dos objetivos almejados poderá revelar-se virtuoso na prática, se os intérpretes e aplicadores do direito estiverem dispostos a operacionalizá-lo de forma adequada, do mesmo modo que textos precisos e tecnicamente bem formulados poderão apresentar resultados práticos insuficientes caso não sejam aplicados da forma prevista. O contexto histórico, cultural, político e socioeconômico é, portanto, fundamental na compreensão da efetividade de mudanças de larga envergadura como as que temos tratado.

Considerando o direito como uma prática interpretativa imbuída a instituições e moldada por tradições culturais, a efetividade de quaisquer fontes jurídicas é, inexoravelmente, matizada por elementos institucionais e culturais. Como advertiu Capelletti: 
A melhor maneira de mesurar o impacto seria aquela que considera instituições e pessoas, culturas e atitudes bem como as regras, pois a autoridade das regras em si é condicionada e qualificada por esses elementos do mundo real. ${ }^{60}$.

Para o presente estudo, a cultura jurídica torna-se fator de extrema relevância, na medida em que a forma de construção das decisões colegiadas do Tribunal, incluindo os procedimentos de deliberação e as formas de estruturação e justificação decisórias, interfere, diretamente, na forma como pode ser operacionalizada a vinculação do Judiciário às decisões da corte constitucional ou mesmo dela própria em casos futuros semelhantes. O modelo deliberativo e decisório do Tribunal já foi abordado no capítulo dedicado ao desenho institucional e as práticas institucionalizadas do STF. Desse modo, o presente capítulo ocupar-se-á das peculiaridades de estruturação e justificação decisória.

A forma pela qual as decisões judiciais são estruturadas e justificadas é de extrema importância na implementação de formas de vinculação judicial a precedentes. Quando decisões tomadas por juízes podem interferir nas escolhas feitas pelos demais ou por eles mesmos em situações posteriores, a explicitação clara das razões de decidir assumem caráter decisivo, de vez que decisões posteriores serão associadas às justificativas decisórias extraídas do precedente. Nesse sentido, Michele Taruffo sustenta que "como precedentes são julgamentos e são, essencialmente, baseados na ratio decidendi de casos, o modo pelo qual julgamentos são estruturados e opiniões são escritas exerce influência sobre sua força e conteúdo.".

60 Mauro Capelletti, 'The Doctrine of Stare Decisis and the Civil Law: A Fundamental Difference - or no Difference at All?', In: Festschrift für Konrad Zweigert zum 70. Geburstag, Tübingen, J.C.B. Mohr, 1981. 
O autor continua:

“Além disso, o estilo das decisões judiciais influencia em como eles são usados como precedentes por juízes de casos subsequentes. Olhando para uma possível tipologia de estilos judiciais, uma distinção pode ser feita entre dois modelos ideais (e extremos). $\mathrm{O}$ primeiro é aquele do estilo legalista, dedutivo e magisterial, no qual o dispositivo final da decisão é apresentado como conseqüência última e necessária de uma série de argumentos legais e lógicos, que são formalmente estruturados como uma demonstração. Argumentos são expressos em uma linguagem neutra, oficial e dotada de autoridade e, normalmente, assumem a forma dedutiva ou silogística. $\mathrm{O}$ outro modelo, no extremo oposto, é aquele de estilo substantivo, discursivo e personalizado. A decisão é sustentada por argumentos diversos, concorrentes ou convergentes, incluindo julgamentos de valor e opiniões pessoais do juiz. Ele lida com os méritos específicos do caso e os argumentos são expressos em linguagem comum e em uma forma discursiva (grifos meus) ${ }^{61,}$.

$\mathrm{Na}$ tipologia trabalhada por Taruffo, o modelo decisório do STF aproximar-se-ia mais do estilo substantativo, discursivo e personalizado, sobretudo pela individualização dos votos. Ainda que possa haver votos de estilo legalista, uma das características centrais na forma como são conduzidos os julgamentos do tribunal é a subversão do próprio caráter colegiado pela tomada de votos individuais. Essa particularidade do modelo decisório do STF

${ }^{61}$ Michele Taruffo, "Institutional factors influencing precedents"; In: MACCORMICK, N., SUMMERS, R. (ed), Interpreting precedents: a comparative study, Vermont: Ashgate Publishing, 1997, p. 448 e 449. 
tem consequências relevantes no que concerne à possibilidade de que suas decisões possam ser seguidas posteriormente por outros juízos, estejam eles vinculados ou não.

Como razões de decidir são articuladas em votos individuais, nem sempre convergentes na sua fundamentação, ainda que o sejam nas conclusões finais, não há, em muitos casos, uma ratio decidendi da corte para a decisão tomada. Ao fim e ao cabo, tem-se um dispositivo decisório carente de fundamentos comuns, de modo que somente poderá ser replicável como precedente em uma situação inteiramente igual. Em casos decididos de forma unânime ou quando a maioria se forma em torno de um voto único, sem argumentações concorrentes, a aplicação de precedentes não revela grandes dificuldades. Em uma minoria de casos mais complexos, contudo, a formulação e justificação decisória individualizada é um fator que obstaculiza a replicação do racicionio juridico que fundamenta o precedente e, desse modo, a construção de generalizações que permitam a aplicação do precedente em um caso posterior, seja para fundamentar uma decisão, seja para afastar a regra extraída em razão da preponderância de razões diversas.

Ademais, não há, de praxe, juízo prospectivo acerca dos efeitos da replicação posterior da decisão tomada. Como sustentei anteriormente, a simples atribuição de autoridade normativa a precedentes não deveria ser um divisor de águas entre a atividade decisória que se vincula ou não a precedentes, na medida em que o ato de subsunção de uma situação fática a uma regra extraída de uma fonte, seja ela uma fonte judicial ou legislativa, é estruturalmente o mesmo. Contudo, a cultura de valorização dos precedentes implica alguma consciência do potencial criativo da atividade decisória, que consubstancia regras replicáveis em casos a serem julgados posteriormente.

O juízo prospectivo que tem lugar na justificação decisória implica não apenas a consideração dos efeitos da replicação em larga escala da decisão 
tomada, mas também na explicitação clara das razões determinantes para a construção do precedente, de modo que possa ser corretamente interpretado e replicado. Desse modo, a atividade decisória que leva a sério precedentes judiciais dialoga não apenas com o passado, ao referir-se a precedentes potencialmente aplicáveis, interpretando-os e deles extraindo regras a serem aplicáveis ou afastadas argumentativamente, mas também com o futuro, porquanto é consciente de que decisões posteriores igualmente deverão levar em conta a decisão que está sendo tomada se houver similaridade entre as situações fático-jurídicas em questão.

\section{Nesse sentido, Frederick Schauer afirma:}

The traditional perspective on precedent, both inside and outside of law, has therefore focused on the use of yesterday's precedents in today's decisions. But in an equally if not more important way, an argument from precedent looks forward as well, asking us to view today's decision as a precedent for tomorrow's decision makers. Today is not only yesterday's tomorrow; it is also tomorrow's yesterday. A system of precedent therefore involves the special responsibility accompanying the power to commit the future before we get there ${ }^{62}$.

Diante das práticas deliberativas e dos procedimentos decisórios, as reformas adotadas nas últimas décadas no Brasil não foram suficientes para garantir modificações substanciais nas formas de estruturação e justificação das decisões. Ainda que se tenha discutido na jurisprudência recente do STF a

${ }^{62}$ FREDERICK SCHAUER, Precedent, Stanford Law Review February, 198739 Stan. L. Rev. 57 
possibilidade de vinculação dos fundamentos de suas decisões ${ }^{63}$, tese que ficou conhecida como vinculação de motivos determinantes, todas as modificações normativas que introduziram algum mecanismo de vinculação judicial a decisões previamente tomadas não se prenderam a necessidade de interpretação de precedentes. Como tão somente o dispositivo decisório é alvo necessário da concordância da maioria, é apenas ele que é tornado vinculante nas decisões em controle concentrado - o que igualmente se tentou reproduzir no controle difuso sob o argumento da mutação constitucional. Já as súmulas, ao implicar nova deliberação entre os ministros, demanda convergência em torno de um enunciado bastante similar a um dispositivo final de uma decisão, que, desse modo, prescinde de grande esforço interpretativo. Nesses termos, dificilmente pode-se falar em uma aproximação entre o que se tem tentado adotar e modelo decisório próprio de sistemas que seguem uma doutrina de stare decisis.

Da forma como tem sido introduzida, a vinculação de decisões endereça-se a solução de problemas de massa. A verticalidade dessas reformas, interessadas em vincular cortes inferiores e, desse modo, evitar a chegada de novos recursos nas instâncias superiores, sobretudo no STF, demonstra que o que se valoriza é o ato de vincular instâncias inferiores e não o precedente da corte superior.

\footnotetext{
${ }^{63}$ Nesse sentido, ver: Rcl 2.363, Rel. Min. Gilmar Mendes, Plenário, DJ 1.04.2005; Rcl 4.692MC, Rel. Min. Cezar Peluso, decisão monocrática, DJ 14.11.2006; Rcl 4.387-MC, Min. Rel. Celso de Mello, decisão monocrática, DJ 2.10.2006; Rcl 5.389 - AgR / PA; Rcl 4.416-MC, Min. Celso de Mello, decisão monocrática, DJ 29.09.2006; Rcl 1.987, Rel. Min. Maurício Corrêa, DJ 21.05.2004; e Rcl 2.291-MC, Rel. Min. Gilmar Mendes, decisão monocrática, DJ 1.04.2003.
} 
Mesmo a tese da vinculação dos motivos determinantes - que, adotada, poderia garantir uma progressiva modificação da forma de justificação decisória, na medida em que apenas uma fundamentação judicial dotada de unidade e clareza poderia ser atribuída de efeito vinculante - pode ser entendida como tentativa de vincular cada vez mais as instâncias inferiores. Ao consubstanciar-se como uma reinterpretação dos efeitos das decisões em controle de constitucionalidade pelo próprio tribunal, a vinculação dos motivos determinantes atribuiria ainda maior poder de vinculação às suas decisões, bloqueando não apenas a chegada de casos que desrespeitassem o dispositivo decisório vinculante, mas também os fundamentos juridicos da decisão precedente quando em uma situação análoga.

Diante do problema da sobrecarga de trabalho do Judiciário como um todo e do STF em particular, sobretudo em razão da avalanche de casos repetitivos resultantes do caráter bastante analítico da Constituição de 1988, a vinculação de decisões das formas como tem sido introduzido de fato pode garantir resultados auspiciosos no sentido de promover a racionalização das atividades da corte e reduzir o tempo despendido como última instancia recursal. Modificações mais profundas na formulação e justificação decisória, contudo, poderiam ter impactos de muito maior alcance, ao facilitar a interpretação e replicação de suas decisões. 


\section{Conclusão}

Desde a promulgação da Constituição de 1988, uma avalanche de processos abarrotou o Judiciário, tornando imperativas reformas que buscassem a racionalização do trabalho das cortes e o aumento da produtividade dos juízes. De um modo geral, as medidas que instituíram mecanismos de vinculação judicial a precedentes endereçaram estes problemas, obstando a admissão de recursos e facilitando a replicação automática de decisões proferidas pelas cortes superiores, sobretudo as do STF.

As modificações normativas introduzidas nesse sentido deixaram incólumes, entretanto, fatores institucionais e culturais determinantes na operacionalização de práticas decisórias pautadas na aplicação de precedentes anteriores. Nesse sentido, as formas de deliberação entre Ministros do STF, a tomada individual de votos e a maneira de estruturação e justificação das decisões judiciais são fatores que dificultam a plena reprodução dos raciocínios jurídicos subjacentes aos precedentes da corte constitucional brasileira, sobretudo em casos complexos em que a decisão não é tomada por unanimidade ou quando a maioria carece de um voto único condutor ou, ao menos, de razões comuns em todos os votos que concluem no mesmo sentido.

A previsão regimental de tomada de votos individuais, combinada à praxe de formulação prévia de votos em gabinetes a portas fechadas, obstaculiza o debate, a propensão à mudança de posicionamentos e, desse modo, à produção de decisões do tribunal como instituição e não como um agregado de juízes que não conversam entre si. Os julgamentos realizam-se pelo somatório dos posicionamentos individuais, de modo que há tantas 
decisões quantos forem os votos proferidos, cada qual com razões de decidir diversas, ainda que haja convergência na decisão final.

Para além de desvirtuar a própria essência do julgamento colegiado, o modelo decisório da corte dificulta a interpretação de suas decisões por instâncias inferiores. O resultado é ausência de parâmetros claros sobre a interpretação constitucional do STF, o que poderia pautar a atividade decisória de outros juízos, a atuação dos demais poderes no exercício de suas funções normativas e mesmo da sociedade civil, quando imbuída de legitimidade ativa para provocar o tribunal.

A dificuldade de compreensão e interpretação das decisões colegiadas do STF é, ainda, acrescida à quantidade monumental de casos julgados anualmente e à extensão de cada uma das decisões tomadas, que chegam a somar milhares de páginas. Inviabilizada a cognoscibilidade das decisões, seria temerário atribuir efeitos vinculantes a algo além dos dispositivos finais da decisão, ainda que se discuta, hodiernamente, na jurisprudência do Supremo a tese da vinculação dos motivos determinantes.

De uma forma geral, as reformas analisadas neste trabalho não interferem nas práticas consolidadas da corte. Pelo contrário, chancelam o modelo deliberativo e decisório do STF, almejando tão somente reduzir a sobrecarga de trabalho mediante a uniformização jurisprudencial e obstamento de recursos. Revelam, desse modo, uma maior preocupação com a vinculação dos juízos inferiores do que uma valorização dos precedentes da corte.

O efeito vinculante é atribuído tão somente ao dispositivo final das decisões. No caso das súmulas, contorna-se a ausência de fundamentos comuns pela reinterpretação pelos próprios ministros de seus precedentes, de modo que se decida, na formulação do enunciado sumular, o que de fato será tornado vinculante. Já na repercussão geral, conquanto se tenha fortalecido a 
capacidade do tribunal de selecionar os casos que julgará, a vinculação operase apenas em relação aos casos sobrestados até a prolação da decisão final. Ademais, se, da parte do legislador, a formulação do instituto foi deveras cautelosa, de parte do STF, sua implementação não foi menos tímida, de vez que, diante de dezenas de milhares de processos ao ano, não há como se imaginar que apenas casos de extrema relevância econômica, social, política ou jurídica estejam sendo julgados pela corte em sede de controle difuso de constitucionalidade.

Não se deve ignorar, contudo, que algumas modificações foram introduzidas há apenas um lustro. $\mathrm{E}$, diante dos dados relativos à quantidade de casos que chegam à corte, seus resultados não são negligenciáveis. Não obstante o STF ainda decidir dezenas de milhares de casos, a redução recente pode assegurar progressiva mudança de perfil do tribunal, que deixa de se ocupar tanto com atividades de última instancia recursal e poderá, assim, dedicar-se mais a atividades próprias de uma corte constitucional.

Ainda que se trate de um processo em curso, que, por ora, opera modificações tão somente no plano normativo, é possível que a introdução progressiva de mecanismos de vinculação de instâncias inferiores possa incorporar mudanças mais profundas na praticas deliberativas da corte e na condução discursiva de seus julgados.

O objetivo do presente trabalho foi, assim, desmistificar os impactos dos mecanismos de vinculação judicial, demonstrando que a simples análise de suas particularidades normativas é insuficiente para se aferir o verdadeiro potencial de mudança no sistema jurídico brasileiro. Conquanto a simples atribuição de autoridade normativa a precedentes não deva implicar mudanças substantivas no ato de subsunção de fatos a normas, é possível que a prática decisória dotada de efeitos de vinculação de outros juízos leve a incorporação de preocupações concernentes à objetividade e clareza decisória, bem como 
juízos prospectivos acerca dos efeitos possíveis da replicação das decisões tomada em larga escala e, ainda, maior preocupação em manter a coerência com os julgados anteriores da própria corte. Ao fim e ao cabo, a coerência é fator que agrega legitimidade e quanto mais próximo do desenho institucional de uma efetiva corte constitucional, maior será a necessidade de reafirmação da legitimidade democrática do tribunal. 


\section{Bibliografia}

ALEXY, Robert, PECZENIK, Aleksander, 'The concept of coherence and its significance for discursive rationality', Ratio Iuris, 3, 1991.

ALEXANDER, Larry, 'Constrained by Precedent', Southern California Law Review, v. 63, 1989, p.1-6.

AMAR, Vikram e TUSHNET, Mark (ed.). Global Perspectives on Constitutional Law. Oxford: Oxford University Press, 2008.

ARANTES, Rogério e COUTO, Cláúdio, "Porque muda e como muda a constituição? Problemas de controle sobre a agenda governamental.”, 32o Encontro Anual da ANPOCS, set/2008.

BELL, J., 'Comparing Precedent', book review of MacCormick \& Summer (1997), Cornell Law Review, v. 82, 1997, p. 1243-1278.

BENDITT, T. M., 'The Rule of Precedent', In: Goldstein, Laurence, Precedent in Law, Oxford: Oxford University Press, 1987.

BICKEL, Alexander Mordecai. The least dangerous branch: the Supreme Court at the bar of politics. 2. ed., New Haven: Yale University, 1986.

BRASIL JÚNIOR, Samuel Meira, Precedentes Vinculantes e Jurisprudência Dominante na Solução de Controvérsias, Tese de doutorado, São Paulo: Faculdade de Direito da Universidade de São Paulo, 2010.

BUSTAMANTE, Thomas da Rosa de, 'Principles, precedents and their interplay in legal argumentation: how to justify analogies between cases', In 
On the Nature of principles, Martin Borowski (ed.), ARSP, Forthcoming, 2010 .

., Uma teoria normativa do precedente judicial: o peso da jurisprudência na argumentação jurídica. Tese de Doutorado. Rio de Janeiro: PUC-Rio, 2007.

CAPELlETTI, Mauro, Juizes Legisladores?, Porto Alegre: Sergio Antonio Fabris, 1993.

., The judicial process in comparative perspectives, Oxford: Clarendon Press Oxford, 1989.

., 'The Doctrine of Stare Decisis and the Civil Law: A Fundamental Difference - or no Difference at All?', In: Festschrift für Konrad Zweigert zum 70. Geburstag, Tübingen, J.C.B. Mohr, 1981.

.,'The Law-making Power of the judge and its limits', Monash U. L. Rev. 15, 1981-1982

., 'Repudiando Montesquieu? A expansão da legitimidade da 'Justica Constitucional", 35 Catholic University Law Review, p. 1000110032, 1985.

CARMINKER, Evan, 'Why must inferior courts obey superior court precedents?' 46 Stanford Law Review, 817 1993-1994.

CARVALHO, Leon Rogério Gonçalves de, O regime jurídico-constitucional das súmulas vinculantes no contexto da atividade normativa do Poder Judiciário, Dissertação de Mestrado, São Paulo: Faculdade de Direito da Universidade de São Paulo, 2010. 
CLAYTON, Cornell W., GILMAN, Howard, Supreme Court DecisionMaking, Chicago: The University of Chicago Press, 1999.

COUTINHO, Diogo, Direito, desenvolvimento e desigualdade: a dimensão jurídica das políticas sociais, São Paulo: Faculdade de Direito da Universidade de São Paulo. Tese de livre docência, 2006.

CONSELHO NACIONAL DE JUSTIÇA, Relatório Justiça em Números 2003, Variáveis e indicadores do Poder Judiciário, Conselho Nacional de Justiça Brasília: CNJ, p. 205 e 206, Disponível em: http://www.cnj.jus.br/images/pesquisasjudiciarias/Publicacoes/relatorio jn2013.pdf

CONSELHO NACIONAL DE JUSTIÇA, Justiça em números 2013: ano-base 2012/ Conselho Nacional de Justiça - Brasília: CNJ, p. 184. Disponível em: http://www.cnj.jus.br/images/stories/docs_cnj/relatorios/justica_numeros_2003 .pdf

DALESSIO, Beatriz Alencar, Senado federal e o STF: um estudo sobre a suspensão de lei declarada inconstitucional, São Paulo: Sociedade Brasileira de Direito Público, 2012. Disponível em: http://www.sbdp.org.br/arquivos/monografia/205_Beatriz\%20A.\%20Dalessio \%20-\%20Monografia $\% 20(2) \% 20(1)$.pdf.

DAKOILAS, Maria, O setor judiciário na América Latina e no Caribe elementos para reforma, Documento Técnico 319 do Banco Mundial, Washington, 1996.

DWORKIN, R., Justice for Hedgehogs, London: The Belknap Press of Harvard University Press, 2011. 
FRANKENBERG, Günter 'Comparing constitutions: Ideas, ideals, and ideology - toward a layered narrative', I-CON, Volume 4, Number 3, 2006, pp. 439-459.

FILHO, Pedro Luiz do Nascimento, Medida cautelar em ação direta de inconstitucionalidade, São Paulo: Sociedade Brasileira de Direito Público, 2007.

GINSBURG, Tom e KAGAN, Robert A., Institutions and Public Law, Comparative approaches, New York: Peter Lang Publishing Inc., 2005

GLOPPEN, S., Wilson, B., GARGARELlA, R., Skaar, E., Kinander, M., Courts and Power in Latin America and África, New York: Palgrave Macmillan, 2010.

GOODHART, A.L., 'Determining the Ratio Decidendi of a Case', Yale Law Journal, v. 40, 1930, p. 161-183.

., 1959, 'The Ratio Decidendi of a Case', Modern Law Review 22:

$117-124$

GOLDING, M., Legal Reasoning, Peterborough, Ontario: Broadview, 2001.

GOLDSTEIN, Laurence, Precedent in Law, Oxford: Oxford University Press, 1987.

GOLDSWORTHY, Jeffrey, Interpreting Constitutions: A comparative study, 2005.

., Questioning the migration of constitutional ideas: rights, constitutionalism and the limits of convergence. In : The Migration of Constitutional Ideas. Sujit Choudhry (ed). Cambridge University Press, 2006. Pp. 142/178. 
GUARNIERI, Carlo, PEDERZOLI, Patrizia, The power of judge, a comparative study of courts and democracy, Oxford: Oxford University Press, 2002.

HIRSCH, Ran, Towards Juristocracy: the origins and consequences of the new constitutionalism, Harvard University Press, 2004.

HURLEY, S. L., 'Coherence, Hypothetical Cases, and Precedent', Oxford Journal of Legal Studies, v.10, p. 221-251, 1990.

JUNQUEIRA, Maria Olívia Pessoni, A construção da súmula vinculante pelo STF: observação dos dezesseis primeiros enunciados de súmula vinculante editados, Monografia de conclusão da Escola de Formação, 2009, disponível em http://www.sbdp.org.br/ver_monografia.php?idMono=149

LAMOND, Grant, 'Do Precedents Create Rules?', Legal Theory, Cambridge: Cambridge University Press, v. 15, p. 1-26, 2005.

., 'Precedent and Analogy in Legal Reasoning', Stanford Encyclopedia of Philosophy, 2006.

LEAL, Roger Stiefelmann. $O$ efeito vinculante na jurisdição constitucional, São Paulo: Saraiva, 2006.

LEAL, Victor Nunes, 'A súmula do Supremo Tribunal e o restatement of the law dos americanos'. São Paulo: LTR, ano 30, jan/fev, 1966, p.7

., 'Sobre as causas que deram origem as súmulas', Revista Forense, Rio de Janeiro, v. 208, ano 61, 1964.

.,'Atualidade do Supremo Tribunal', Revista de Direito Administrativo 78 (1964), pp. 453-459. 
LUCY, William, 'Adjudication', in Jules Coleman e Scott Schapiro, The Oxford Notebook of Jurisprudence and Philosophy of Law, Oxford: Oxford University Press, 2002.

LEGRAND, Pierre, "Against a European Civil Code", Modern Law Review, 60:44-63, 1997.

., “How to Compare Now”, Legal Studies, 16: 232-242, 1996.

MACCORMICK, N., SUMMERS, R. (ed), Interpreting precedents: a comparative study, Vermont: Ashgate Publishing, 1997.

., Legal Reasoning and legal Theory, New York: Oxford University Press, 2003.

, Precedent as a Source of Law, in. Attwool, Elspeth; Comanducci, Paolo (orgs.), Sources of Law and Legislation: Proceedings of the 17th World Congress of Philosophy of Law and Social Philosophy (IVR), Bologna, June 16-21, 1995, in. ARSP-B, Vol. 69, 1998, p. 177-85.

MARCATO, Antonio Carlos, Crises da Justiça e influência dos precedentes judiciais no Direito Processual Civil Brasileiro, Tese apresentada ao concurso para o cargo de Professor Titular de Direito Processual Civil da Faculdade de Direito da USP, São Paulo, 2008.

MENDES, Conrado Hübner. Direitos fundamentais, separação de poderes $e$ deliberação, Tese de Doutoramento, São Paulo: Faculdade de Filosofia, Letras e Ciências Humanas da Universidade de São Paulo, 2008.

. “Onze ilhas". Folha de S. Paulo, São Paulo, 1 de fevereiro de 2010, Tendências/Debates, disponível em: http://www1.folha.uol.com.br/fsp/opiniao/fz0102201008.htm. 
MOORE, M., 'Precedent, Induction, and Ethical Generalization', In GOLDSTEIN, Laurence, Precedent in Law, Oxford: Oxford University Press, 1987.

MOREIRA, José Carlos Barbosa., 'Súmula, jurisprudência, precedente: uma escalada e seus riscos'. Revista Síntese de Direito Civil e Processual Civil. Porto Alegre. v.6. n.35. p.5-16. maio/jun. 2005.

NUNES, Jorge Amaury Maia, A segurança jurídica à luz do poder normativo e coercitivo do judiciário: limites à decisão e à recorribilidade por meio de súmulas, São Paulo: 2007.

PERRY, S., 'Judicial Obligation, Precedent and the Common Law', Oxford Journal of Legal Studies, v. 7, 1987, p 215-257.

PESSÔA, Leonel Cesarino (org.), Súmula Vinculante e Segurança Jurídica, São Paulo: LTR, 2007.

REIMANN, Mathias e ZIMMERMANN, Reinhard (ed.) The Oxford Handbook of Comparative Law. Oxford: Oxford University Press, 2006.

ROCHA, Carmen Lúcia Antunes, Sobre a Súmula Vinculante, disponível em: http://www.teiajuridica.com/sul11vinc.html.

ROSAS, Roberto, 'Da súmula à súmula vinculante'. Revista dos Tribunais. São Paulo. v.98. n.879. 2009, p.41-47.

SCHAUER, Frederick, 'Precedent', Stanford Law Review 39 (1987): 571-605. ., Playing by the rules: a philosophical examination of rule-based decision-making in Law and in life, Oxford: Clarendon Law Series, 1991.

SHAPIRO, Martin, Courts, A comparative and political analysis, Chicago: The 
University of Chicago Press, 1981.

SIEDER, R., SCHOJOLDEN, L., ANGELL, A. (ed.), The judicialization of politics in Latin America, New York: Ed.Palgrave - Macmillan, 2005.

SIFUENTES, Monica, Súmula Vinculante: um estudo sobre o poder normativo dos tribunais, São Paulo: Ed. Saraiva, 2005.

SILVA, Evandro Lins e. 'A questão do efeito vinculante'. Revista da Ordem dos Advogados do Brasil, v. 25, n. 61, jul./dez. 1995, p. 53 - 58.

SILVA, Virgilio Afonso da, "O STF e o controle de constitucionalidade: deliberação, diálogo e razão pública", in Revista de Direito Administrativo 250, 2009, p.197-227.

., MENDES, Conrado Hubner, "Entre a transparência e o populismo judicial", In: Jornal Folha de São Paulo, São Paulo, 11 de maio de 2009, Tendências/debates. Disponível em: http://www1.folha.uol.com.br/fsp/opiniao/fz1105200908.htm.

STRECK, Lênio, Súmulas no direito brasileiro: eficácia, poder e função, Porto Alegre: Ed. Livraria dos Advogados, 1995.

SORIANO, Leonor Moral, Precedents: reasoning by rules and reasoning by principles, In Rhetoric and the rule of Law: an author's Day with Neil MacCormick.

SUNDFELD, Carlos Ari (coord), Relatório final de pesquisa do projeto “Judicialização da política e demandas por juridificação: o Judiciário frente aos outros poderes e frente à sociedade", São Paulo: Sociedade Brasileira de Direito Público, 2012.

TAVARES, André Ramos, Perplexidades do novo instituto da súmula 
vinculante no direito brasileiro', Revista Brasileira de Direito Público 5 (2006): 147-161.

., 'Regime da Súmula Vinculante', Carta Forense, São Paulo, p. 24, publicado em 01 dez. 2004

TATE, C. Neal; VALLINDER, Torbjörn. The Global Expansion of Judicial Power. Nova York: New York University Press, 1995

TUCCI, José Rogério Cruz e, Precedente judicial como fonte do direito, São Paulo: Editora Revista dos Tribunais, 2004.

TUSHNET, Mark, Taking the Constitution Away from the Courts, New Jersey: Princeton University Press, 1999.

VERÍSSIMO, Marcos Paulo, 'A constituição de 1988, vinte anos depois: suprema corte e ativismo judicial "à brasileira". Revista Direito GV, v. 4, p. 407-440, 2008.

., A judicializacao dos conflitos de justiça distributiva: o processo judicial no pós-1988, São Paulo: Faculdade de Direito da Universidade de São Paulo. Tese de doutorado, 2006.

VOJVODIC, Adriana de Moraes, Precedentes e argumentação no Supremo Tribunal Federal: entre a vinculação ao passado e a sinalização para o futuro, São Paulo: Faculdade de Direito da Universidade de São Paulo, Tese de doutorado, 2012.

WADDAMS, Stephen, Dimensions of Private Law: Categories and Concepts in Anglo-American Legal Reasoning, Cambridge: Cambridge University Press, 2003.

WALUCHOW, W.J., A Common Law Theory of Judicial Review: The Living 
Tree. Cambridge. Cambridge University Press. 2007.

WEINRIB, E. J., The idea of private law, Harvard University Press, 1995.

ZWEIGERT, K. E KÖTZ, H, An introduction to comparative law, 3rd Ed, Oxford: Oxford University Press, 1977 